\title{
Melatonin in Plant Defense against Abiotic Stress
}

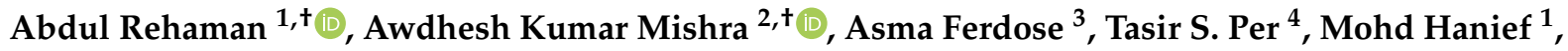 \\ Arif Tasleem Jan ${ }^{1}$ (D) and Mohd Asgher ${ }^{1, *(D)}$
}

1 School of Biosciences and Biotechnology, Baba Ghulam Shah Badshah University, Rajouri 185234, India; abdulrehaman9699@gmail.com (A.R.); haniefdu@gmail.com (M.H.); atasleem@bgsbu.ac.in (A.T.J.)

2 Department of Biotechnology, Yeungnam University, Gyeongsan 38541, Gyeongsangbuk-do, Korea; awdhesh@ynu.ac.kr

3 Department of Zoology, Baba Ghulam Shah Badshah University, Rajouri 185234, India; asmaferdose83@gmail.com

4 Department of Higher Education, Jammu and Kashmir, Jammu 180001, India; tasirbot@gmail.com

* Correspondence: asghermohd@gmail.com

+ Authors contributed equally to writing of the manuscript.

Citation: Rehaman, A.; Mishra, A.K.; Ferdose, A.; Per, T.S.; Hanief, M.; Jan, A.T.; Asgher, M. Melatonin in Plant Defense against Abiotic Stress. Forests 2021, 12, 1404. https://doi.org/ 10.3390/f12101404

Academic Editor: Domingo Sancho-Knapik

Received: 8 August 2021

Accepted: 30 September 2021

Published: 15 October 2021

Publisher's Note: MDPI stays neutral with regard to jurisdictional claims in published maps and institutional affiliations.

Copyright: (C) 2021 by the authors. Licensee MDPI, Basel, Switzerland. This article is an open access article distributed under the terms and conditions of the Creative Commons Attribution (CC BY) license (https:// creativecommons.org/licenses/by/ $4.0 /)$.

\begin{abstract}
Abiotic stress adversely affects plant growth and metabolism and as such reduces plant productivity. Recognized as a major contributor in the production of reactive oxygen species (ROS), it hinders the growth of plants through induction of oxidative stress. Biostimulants such as melatonin have a multifunctional role, acting as a defense strategy in minimizing the effects of oxidative stress. Melatonin plays important role in plant processes ranging from seed germination to senescence, besides performing the function of a biostimulant in improving the plant's productivity. In addition to its important role in the signaling cascade, melatonin acts as an antioxidant that helps in scavenging ROS, generated as part of different stresses among plants. The current study was undertaken to elaborate the synthesis and regulation of melatonin in plants, besides emphasizing its function under various abiotic stress namely, salt, temperature, herbicides, heavy metals, and drought. Additionally, a special consideration was put on the crosstalk of melatonin with phytohormones to overcome plant abiotic stress.
\end{abstract}

Keywords: abiotic stress; biostimulants; melatonin; phytohormones; plants

\section{Introduction}

Abiotic stresses including extremes of temperature, drought, salinity etc, greatly influence plant growth and productivity [1-3]. It has been estimated that about $90 \%$ of arable land is prone to one of the above-mentioned stresses [4]. Furthermore, abiotic stresses show progressive development under the current era of global climatic change [5,6] and pose a great threat to sustainability in agriculture worldwide. Often correlated with a decrease in the soil water level, any significant reduction in the cultivable capacity of the soil often occurs with a change in the land use pattern from that typical of a fertile to marginal one $[7,8]$. It affects growth and development of crop plants via a reduction in germination, a decrease in the photosynthetic activity and carbon assimilation to a large extent, decreased flowering, and pollen sterility, and as such, acts as a major limiting factor for crop yield [9-12]. Abiotic stresses affecting different stages of plant growth constitute about $70 \%$ of the losses in yield among major crop plants like rice, wheat, corn, etc. [13-16].

Biostimulants include substances of both natural and synthetic origin, that, on applying to plants, influence their growth via changes in vital processes. Biostimulants thereby help in mitigating stress conditions. As stresses often cause frequent remodelling of the plant's defence system as adjustment to the change in environment $[17,18]$, biostimulants prime plants to sensitize and enhance their defence strategies in order to respond effectively in combatting effects exerted by an ever-changing environment [19-23]. Reducing the need of fertilizers, they impart tolerance to different kinds of stresses and as such cause increases 
in the crop yield, as well as leading to improvements in the quality of crop product [24,25]. Under continuous exposure to stresses (both biotic and abiotic), the priming of plants by biostimulants offers a novel way to regulate or modify different physiological processes that influence growth and development activities in plants. Stimulation of plant defence machinery is currently being explored as an emerging strategy to enhance crop productivity and resilience to changing climatic conditions. Keeping in view immune priming of plants that offer the potential of imparting resistance against different environmental stresses, the current study was undertaken to elaborate the role of melatonin in plant growth and development, with special emphasis on its crosstalk with plant hormones in enhancing plant productivity, besides having information in promoting and sensitizing plant defense to overcome the ill effects of different abiotic stresses.

\section{Melatonin as a Bio-Stimulatory Molecule}

Plant growth regulators are the multifunctional molecules involved in regulating the growth and development of plants, besides attributing the property of abiotic stress tolerance $[9,26,27]$. Of them, production of melatonin ( $N$-acetyl-5-methoxytryptamine) is well established among the majority of monocotyledons and dicotyledons families [28,29]. Despite its production in the mitochondria and chloroplast of roots and leaves, its translocation to meristems, flowers and fruits promotes growth of aerial parts of the plant [30-32]. It is found in higher amounts in reproductive tissues that are young and decline in senescence tissues. In a study, Van Tassel et al. observed that melatonin content is higher in two-day old seedlings of Pharbitis nil (L.) compared with older seedlings [33]. In Brassica juncea (L.), application of $0.1 \mathrm{mM}$ concentrations of melatonin increases root growth, while higher melatonin concentration $(100 \mathrm{mM})$ was found to exert inhibitory effects on the growth of roots [34]. Melatonin at a concentration of $0.1-0.5 \mu \mathrm{M}$ was found to promote regrowth of the frozen shoots [35]. Enhancement in the germination of Cucumis sativus (L.) seeds were observed after treating seeds with $100 \mu \mathrm{M}$ melatonin [36].

\section{Melatonin Biosynthesis in Plants}

Melatonin was first detected in plants in 1995 [37]. Melatonin synthesis in plants was confirmed by an isotope tracer study in Hypericum perforatum (L.) [38]. The biosynthesis of melatonin is well established in plants [39-41]. Melatonin, an indolic substance has its origins in serotonin (5-hydroxytryptamine) [29,41,42]. Sharing a common biosynthetic precursor i.e., 5-hydroxytryptophan, their synthesis is reported in both animals and plants $[38,41,43]$. In one study, the role of the tryptamine pathway (Tryptophan Tryptamine-Serotonin) in the production of serotonin was well established [44]. Melatonin is biosynthesized in four pathways. In plants, tryptophan decarboxylase converts tryptophan into tryptamine in cytoplasm which undergoes further conversion to serotonin upon catalysis by tryptamine-5-hydroxylase in endoplasmic reticulum [29]. The $N$-acetylation of serotonin takes place by enzyme serotonin- $N$-acetyltransferase (SNAT), which converts serotonin into $\mathrm{N}$-acetyl serotonin which, upon methylation either by acetyl-serotonin methyl transferase (ASMT) or by caffeic acid O-methyltransferase (COMT), respectively, leads to production of melatonin in cytoplasm (Pathway I). Serotonin in presence of either ASMT or COMT is converted into 5-methoxyltryptamine in cytoplasm and finally converted into melatonin by SNAT in chloroplast (Pathway II). Tryptophan is converted into 5-hydroxytryptophan by enzyme tryptophan 5-hydroxylase (TPH). 5-hydroxytryptophan is converted into serotonin by Tryptophan decarboxylase (TDC) in cytoplasm. Serotonin in cytoplasm is converted into $N$-acetylserotonin by SNAT and into 5-methoxytrpamine either by ASMT/COMT. $N$-acetylserotonin and 5-methoxytrpamine is converted into melatonin either by ASMT/COMT or by SNAT in cytoplasm and chloroplast respectively [29] (Pathway III and IV).

The biosynthesis of melatonin is briefly described in Figure 1. The Intermediate of Melatonin is found in cytoplasm, endoplasmic reticulum and chloroplasts [29,45]. The expression pattern of genes encoding the biosynthesis of melatonin in salt, drought and 
cold stress has been well studied in Oryza sativa (L.) [46]. In this study, drought stress was found inducing expression of TDC and ASMT genes, while suppressing the expression of T5H and SNAT. In contrast, salt stress causes up-regulation in the expression of TDC, ASMT, and SNAT genes with suppression of T5H. On the other hand, cold stress $\left(4^{\circ} \mathrm{C}\right)$ causes enhancement in the expression of TDC, while inducing suppression of T5H, SNAT, and ASMT genes. Together, it indicates that stress has a pronounced effect on the expression of different genes of the melatonin pathway.

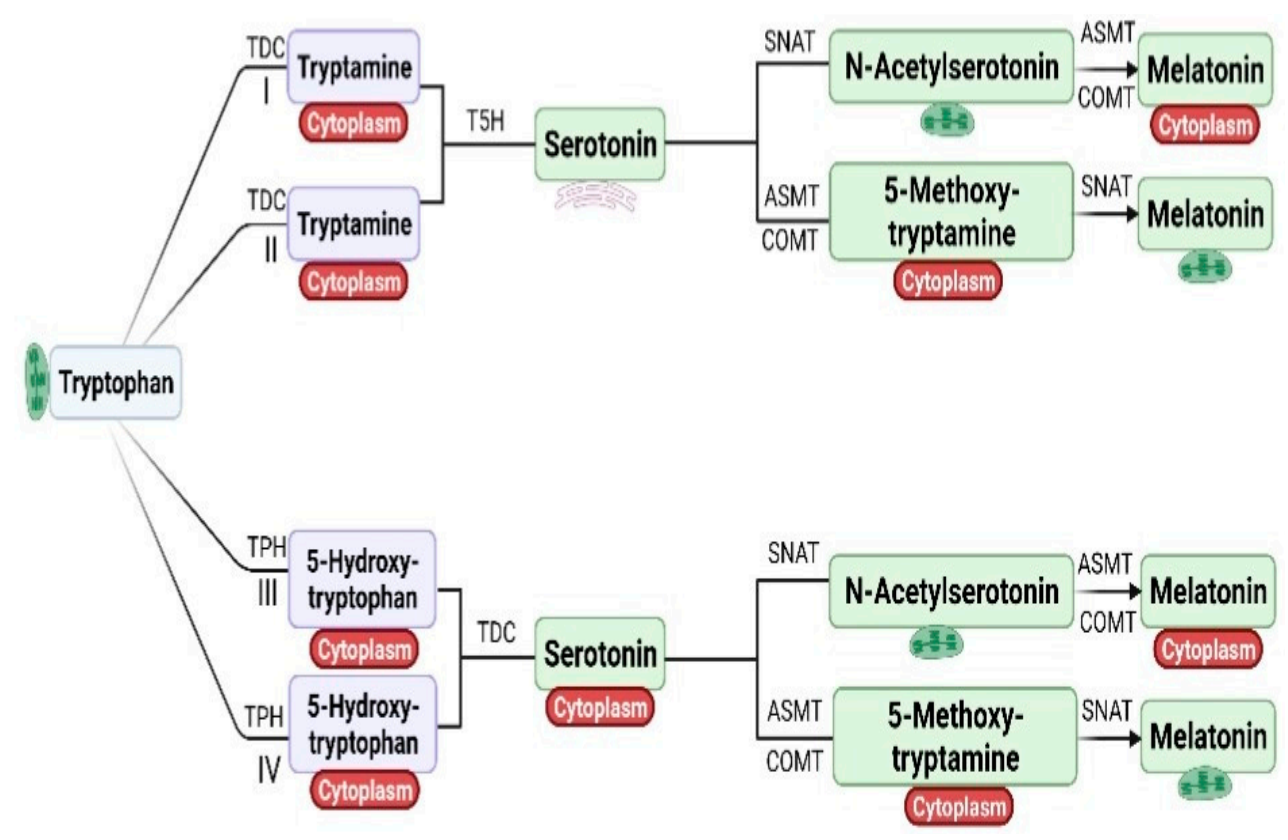

Figure 1. Biosynthesis of melatonin in plants. Abbreviations: TDC, tryptophan decarboxylase; TPH, tryptophan hydroxylase; $\mathrm{T} 5 \mathrm{H}$, tryptophan 5-hydroxylase; SNAT, serotonin $\mathrm{N}$-acetyltransferase; ASMT, $\mathrm{N}$-acetylserotonin methyltransferase; COMT. Caffeic acid O-methyltransferase.

\section{Melatonin as Plant Growth Regulator}

Melatonin-a signaling molecule that acts as a master plant growth regulator, stimulates plant growth and development, besides providing defense to plants against different stresses $[47,48]$. As stresses (both biotic and abiotic) affects the growth of the plants and thereby cause a reduction in the yield, production of melatonin in response to these stresses exerts effects similar to indole-3-acetic acid (IAA) in protecting plants via its involvement in multiple physiological processes $[15,49,50]$. Sharing synthesis from a similar moiety, tryptophan, melatonin performs a regulatory check of plant growth and development [42]. Exogenous application of melatonin causes a reduction in the leaf area in Arabidopsis thaliana (L.) [51], increases gas exchange and yield in Brassica juncea under salt stress [52], accelerates endogenous levels of melatonin by increasing methyl jasmonate (MeJA) accumulation in Citrullus lunatus (Thunb), and increases chlorophyll content in Zea mays (L.) on exposure to drought stress $[53,54]$. It increases germination and photosynthetic activity in Cucumis and Oryza sativa under cold stress [55,56], increases Fv/Fm ratio for Solanum lycopersicum (L.) grown under heat stress [57], and provides tolerance to Nicotiana tabacum (L.) against cadmium [58]. Additionally, melatonin was found capable of regulating its own biosynthesis along with the synthesis of prominent plant growth regulators such as auxin, gibberellins, cytokinin's, ethylene, jasmonic acid, and others. Melatonin increases the accumulation of sugars which enhance the endogenous NO level that induces immunity against bacterial pathogens through salicylic acid and NO-dependent pathway. NO triggers melatonin biosynthesis, and on the other hand, melatonin behaves as an NO scavenger. Both these processes induce changes to hormone levels via the up or downregulation of hormone biosynthesis or catabolism enzymes. Melatonin and NO can induce auxin 
signaling transduction genes. Melatonin has auxin-like activity as it induces root and shoot growth that gives rise to lateral and adventitious roots. Melatonin's role in fruit ripening and post-harvest processes as a gene of ethylene-related factors is similar [32,45] (Table 1).

Table 1. Melatonin functioning in relation to Plant growth regulators under different stress conditions.

\begin{tabular}{ccccc}
\hline Type of Stress & $\begin{array}{c}\text { Melatonin } \\
\text { Dose }\end{array}$ & Plant sp. & $\begin{array}{c}\text { Plant Growth } \\
\text { Regulator }\end{array}$ & Response \\
\hline
\end{tabular}

$100 \mu \mathrm{M} \quad$ Cucumis sativus $\quad$ NO Increased Antioxidants provide

Cold tolerance. Increased PsbA (D1) protein of PSII. Decreased

Cold stress oxidative stress markers such as electrolyte leakage (EL), MDA, and reactive $\mathrm{ROS}$ accumulation. $150 \mu \mathrm{M} \quad$ Citrullus lunatus JA accumulation $\begin{gathered}\mathrm{MeJA} \text { and } \mathrm{H}_{2} \mathrm{O}_{2} \text { accumulation } \\ \text { increased. Melatonin display role }\end{gathered}$ in grafing-induced cold tolerance

Increased germination rate, Hypocotyl length, and starch content. Melatonin regulated
$20 \mu \mathrm{M} \quad$ Gossypium hirsutum L.
Melatonin regulate

ABA and GA genes expression
ABA and GA expression of genes involved in plant signal transduction pathway, and alleviated dormancy

Melatonin induces salt tolerance through the upregulation of ABA responsive genes, Induce antioxidant defense systems, counteract the salt-induced ROS

$10 \mu \mathrm{M} \quad$ Arabidopsis thaliana

ABA overproduction

Salinity stress

$\begin{array}{cc}70 \mu \mathrm{M} & \text { Triticum aestivum } \\ \text { (L.) } & \text { NO scavengerSA }\end{array}$

Increased tissue growth, root and shoot weight, Salinity tolerance

Melatonin and SA induce nitrogen metabolism, Melatonin and SA increased the content of Spd, Spm and Pas

Decreased lipid peroxidation, hydrogen peroxide content, Redox and ion

homeostasis maintenance Improved photosynthesis,

$20 \mu \mathrm{M} \quad$ Triticum aestivum $\quad \mathrm{H}_{2} \mathrm{~S} \quad$ Decreased oxidative
stress markers

$1 \mu \mathrm{M} \quad$ Brassicanapus (L.) $\mathrm{NO}$

Regulate CK biosynthesis genes, Down-regulation of ABA biosynthesis genes, Melatonin supplementation enhanced the endogenous melatonin and CK content reduced content of ABA

Enhanced PAs levels and regulate

temperature

$100 \mu \mathrm{M} \quad$ Lolium perenne (L.) ABA, CK
transcript abundance, Melatonin

$100 \mu \mathrm{M} \quad \begin{gathered}\text { Solanum } \\ \text { lycopersicum }\end{gathered} \quad$ PAs, NO


Table 1. Cont.

\begin{tabular}{|c|c|c|c|c|c|}
\hline Type of Stress & $\begin{array}{l}\text { Melatonin } \\
\text { Dose }\end{array}$ & Plant sp. & $\begin{array}{l}\text { Plant Growth } \\
\text { Regulator }\end{array}$ & Response & Reference(s) \\
\hline pH stress & $5 \mu \mathrm{M}$ & Malus hupehensis & PAs & $\begin{array}{c}\text { Enhanced antioxidantsPAs } \\
\text { content and its gene, } \\
\text { Increased MDA }\end{array}$ & [67] \\
\hline Drought & $20 \mu \mathrm{M}$ & $\begin{array}{c}\text { Agrostis stolonifera } \\
\text { (L.) }\end{array}$ & CK & $\begin{array}{l}\text { Improved photochemical } \\
\text { efficiency, chlorophyll content, up } \\
\text { regulates dehydrated genes, } \\
\text { Cytokinin-signaling and synthesis } \\
\text { genes were prominently } \\
\text { up-regulated in ME-treated } \\
\text { ipt-transgenic plants. }\end{array}$ & [68] \\
\hline $\begin{array}{l}\text { Drought }+ \\
\text { Cold }\end{array}$ & $1 \mathrm{mM}$ & $\begin{array}{l}\text { Hordeum vulgare } \\
\text { (L.) }\end{array}$ & $\begin{array}{l}\text { Higher ABA } \\
\text { accumulation }\end{array}$ & $\begin{array}{c}\text { Better water status, modulating } \\
\text { antioxidant systems and } \\
\text { ABA levels }\end{array}$ & [69] \\
\hline $\mathrm{Pb}$ & $0.1 \mathrm{mM}$ & Zea mays & $\begin{array}{c}\text { NO } \\
\text { Scavenger(cPTIO) }\end{array}$ & $\begin{array}{l}\text { MT in combination with cPTIO } \\
\text { resulted in an elevation } \mathrm{H}_{2} \mathrm{O}_{2} \text {, } \\
\text { MDA contents, and EL } \\
\text { parameters, cPTIO in combination } \\
\text { with MT was ineffective in } \\
\text { changing the activities of enzyme. }\end{array}$ & [70] \\
\hline $\mathrm{Cd}$ & $100 \mu \mathrm{M}$ & Triticum aestivum & $\begin{array}{l}\text { NO scavenger } \\
\text { (cPTIO) }\end{array}$ & $\begin{array}{l}\text { Enhanced growth attributes, } \\
\text { Decreased oxidative stress, } \\
\text { reduced endogenous NO Levels }\end{array}$ & {$[71]$} \\
\hline Fluoride & $20 \mu \mathrm{M}$ & Oryza sativa & $\begin{array}{l}\text { Accumulation of } \\
\text { gibberellic acid } \\
(\mathrm{GA}) \text { and } \\
\text { endogenous ABA, } \\
\text { low indole-3-acetic } \\
\text { acid }\end{array}$ & $\begin{array}{l}\text { Decreased oxidative stress, } \\
\text { promote root and shoot growth, } \\
\text { plant biomass, Decreased } \\
\text { oxidative stress, Increased } \\
\text { Proline accumulation }\end{array}$ & [72] \\
\hline
\end{tabular}

Melatonin's function as a plant growth regulator is owed to its growth-promoting activity and enhancement of yield via the regulation of ion homeostasis [50]. Similarly to auxin and cytokinin, melatonin induces lateral root generation and stimulates root and shoot growth by protecting sub-cellular structures and photosynthetic apparatus and in delaying senescence $[45,73]$. Melatonin stimulates lateral and adventitious root regeneration and cotyledons expansion in young Brassica juncea seedlings and Lupinus albus (L.) $[34,73]$. Its role in regulating the expression of ethylene-related factors adds its role in fruit ripening and post-harvest processes [74-76]. Additionally, melatonin regulates the ABA pathway in Malus hupehensis (Pamp) [77] and upregulates key genes in GA biosynthesis [49].

Melatonin helps to overcome the ill effects of stressors and, as such, acts as an important regulator of plant growth $[41,78]$. Studies have demonstrated the role of melatonin in the detoxification of free radicals (ROS) generated as part of metabolic or photosynthetic activities $[39,52,79,80])$. High concentrations of melatonin reduce ROS in root cells and thereby inhibit ROS-induced cell growth in Glycyrrhiza uralensis (Fisch) [81]. Its effect as an antioxidant helps in controlling the production of reactive oxygen and nitrogen species (ROS, RNS) that impart protection to plants against different stresses [41,42,82]. Melatonin is reported to be more effective than glutathione and vitamin $\mathrm{E}$ in the scavenging of ROS and RNS, besides regulating the activity of superoxide dismutase (SOD), peroxidase (POX), catalase (CAT), and glutathione reductase (GSSG-R) [41]. Exogenous application of melatonin activates antioxidant system in plants that has a positive impact in imparting resistance against different environmental stresses via reduction in the oxidation of proteins, lipids, and nucleic acids $[50,73,83]$. Additionally, melatonin is found to be effective in 
increasing the efficiency of mitochondrial electron transport chains and in reducing the leakage of electrons $[84,85]$.

\section{Melatonin as Stress Reliever}

The environmental conditions that favour plant growth greatly influence the melatonin content of the plants. Plants exposed to sunlight have more melatonin than exposed under artificial light $[86,87]$. The melatonin content shows significant enhancement from 22 (for plants grown in growth chamber) to $142 \mathrm{ng} \mathrm{g}^{-1} \mathrm{f} . \mathrm{w}$ (for plants grown in open field) in the leaves of Solanum lycopersicum [87]. Interaction between melatonin with other plant growth regulators has been studied under stress conditions (Table 2) and found to alleviate or protect plants from different stresses discussed in detail as below:

Table 2. Melatonin functioning under different stress conditions.

\begin{tabular}{|c|c|c|c|c|}
\hline Type of Stress & Melatonin Dose & Plant sp. & Response & Reference(s) \\
\hline \multirow[t]{4}{*}{ Drought } & $50 \mu \mathrm{M}$ & Arabidopsis & $\begin{array}{l}\text { Regulation of the mRNA } \\
\text { expression of various } \\
\text { stress-responsive genes such as } \\
\text { COR15A, RD22, and KIN1, } \\
\text { sucrose accumulation }\end{array}$ & [88] \\
\hline & 4,20, and $100 \mu \mathrm{M}$ & $\begin{array}{l}\text { Cynodon dactylon } \\
\text { (L). }\end{array}$ & $\begin{array}{l}\text { Reduced reactive oxygen species } \\
\text { (ROS), higher antioxidants } \\
\text { metabolism, high concentration of } \\
\text { amino acids, organic acids, sugars, } \\
\text { and sugar alcohols, }\end{array}$ & [89] \\
\hline & $100 \mu \mathrm{M}$ & Malus & $\begin{array}{l}\text { Better water conservation in } \\
\text { leaves, electrolyte leakage less, } \\
\text { increased photosynthetic rate. } \\
\text { Melatonin down- } \\
\text { regulatesMdNCED3, an abscisic } \\
\text { acid (ABA) synthesis gene and } \\
\text { up-regulates catabolic genes } \\
\text { MdCYP707A1 andMdCYP707A2. } \\
\text { Reduced ABA contents and } \\
\text { increases antioxidant enzymes. }\end{array}$ & [77] \\
\hline & $50 \mu \mathrm{M}$ melatonin & Zea mays & $\begin{array}{l}\text { Plant growth and photosynthetic } \\
\text { attributes increases. Antioxidant } \\
\text { enzymes activity increases. }\end{array}$ & [54] \\
\hline \multirow[t]{2}{*}{ Thermotolerance } & $20 \mu \mathrm{M}$ & Arabidopsis & $\begin{array}{l}\text { Upregulation of heat-shock } \\
\text { factors(HSFA1s) }\end{array}$ & {$[90]$} \\
\hline & $(100 \mu \mathrm{mol} / \mathrm{L})$ & Zea mays (L). & $\begin{array}{l}\text { Increased photosynthesis. } \\
\text { Reduced oxidative damage. }\end{array}$ & [91] \\
\hline $\begin{array}{c}\text { Herbicide } \\
\text { Pendimethaline (Pend) } \\
\text { (N-(1-ethylpropyl)-3,4- } \\
\text { dimethyl-2,6- } \\
\text { dinitrobenzenamine) }\end{array}$ & 8,16 and $32 \mathrm{mM}$ & $\begin{array}{l}\text { Capsicum annuum } \\
\text { (L.) }\end{array}$ & $\begin{array}{l}\text { Chlorophyll content and relative } \\
\text { water content reduced. Increase in } \\
\text { carotenoid, proline } \\
\text { and glutathione. }\end{array}$ & [92] \\
\hline Paraquat & $200 \mu \mathrm{M}$ & Pisum sativum (L.) & $\begin{array}{l}\text { Increased photosynthetic } \\
\text { pigments, improved functioning of } \\
\text { the photosynthetic apparatus. } \\
\text { Increased water content }\end{array}$ & [93] \\
\hline Salt & $1 \mu \mathrm{M}$ & Brassica juncea & $\begin{array}{l}\text { Increased plant height, leaf } \\
\text { length/width, and stem diameter. } \\
\text { Increased gas exchange } \\
\text { parameters, relative water content. } \\
\text { Reduced abscisic acid and } \\
\text { increased salicylic acid content. }\end{array}$ & [52] \\
\hline
\end{tabular}


Table 2. Cont.

\begin{tabular}{|c|c|c|c|c|}
\hline Type of Stress & Melatonin Dose & Plant sp. & Response & Reference(s) \\
\hline & $\begin{array}{l}50,100,200,300 \\
\quad \text { or } 500 \mu \mathrm{M}\end{array}$ & $\begin{array}{l}\text { Limonium bicolor } \\
\text { (Bunge) }\end{array}$ & $\begin{array}{l}\text { Higher seed germination, high } \\
\text { content melatonin, High } \\
\text { gibberellic acid (GA), low content } \\
\text { abscisic acid (ABA). }\end{array}$ & [49] \\
\hline & $10 \mu \mathrm{M}$ & Oryza sativa & $\begin{array}{l}\text { Decreasing the sodium content to } \\
\text { maintain } \mathrm{Na}^{+} / \mathrm{K}^{+} \text {homeostasis, } \\
\text { decreased membrane lipid } \\
\text { oxidation, increased } \\
\text { chlorophyll contention. }\end{array}$ & [94] \\
\hline Cold Stress $4{ }^{\circ} \mathrm{C}$ & $150 \mu \mathrm{M}$ & Citrullus lanatus & $\begin{array}{c}\text { Increased accumulation of MeJA } \\
\text { and } \mathrm{H}_{2} \mathrm{O}_{2} \text {, Increased tolerance and } \\
\text { Fv/Fm }\end{array}$ & [53] \\
\hline $4{ }^{\circ} \mathrm{C}$ & $100 \mu \mathrm{mol}$ & $\begin{array}{c}\text { Solanum } \\
\text { lycopersicum }\end{array}$ & Increased Fv/Fm, Increased NPQ & [95] \\
\hline$-5^{\circ} \mathrm{C}$ & $100 \mu \mathrm{M}$ & Cynodon dactylon & $\begin{array}{l}\text { Higher chlorophyll fluorescence } \\
\text { transient (OJIP) curves. Arabinose, } \\
\text { mannose, glucopyranose, maltose, } \\
\text { and turanose) and one organic } \\
\text { acid (propanoic acid) increased. } \\
\text { Valine and threonine } \\
\text { contents reduced. }\end{array}$ & [96] \\
\hline Heavy metals (Lead) & $200 \mathrm{nM}$ & Nicotiana tabacum & $\begin{array}{l}\text { Prevents DNA damage, efficacious } \\
\text { antioxidant and decreased } \\
\text { superoxide radical accumulation. }\end{array}$ & [97] \\
\hline
\end{tabular}

\subsection{Melatonin under Drought Stress}

Drought is the major stress that alters physiological, biochemical, and molecular processes in plants $[11,12,98,99]$. The plants grown in arid and semi-arid regions will face more intense and longer periods of drought [100]. The urgent need of the hour in these changing environmental conditions is to promote adaptive agricultural strategies because numerous levels of sensitivity to water stress are shown by different organs [12,101] Cucumis sativus exposed to melatonin has a higher rate of germination of seeds and root growth when grown in PEG-stressed conditions [36] and reduced drought-promoted leaf senescence in Agrostis [68]. Supply of melatonin in the leaves of Malus domesticus (Borkh) has been shown to delay the senescence as a result of long-term exposure to drought [102]. Applications of melatonin can more prominently increase whole-plant drought tolerance $[77,103]$. Water restrictions during growth are responsible for rise of endogenous melatonin, which is four-fold greater than that of well-irrigated plants, indicating the that melatonin has a signaling role in lupin seedlings [87].

Melatonin application at roots causes reduction in the leaf senescence, along with significant improvement in the efficiency of PSII and enhancement in the antioxidative enzymes, that led authors to propose use of melatonin for agricultural purposes [102,104]. A study on mycorrhizal inoculation of tobacco or application of melatonin alone causes enhancement in the nutrient uptake followed by accumulation of osmolytes; thereby leading to increase in the chlorophyll fluorescence, increased seedling growth with reduced drought stress effects [105]. Heshmati et al. reported seed priming in response to melatonin in a dose dependent manner [106]. Melatonin was found enhancing stability of membranous structures with increase in the performance of antioxidant enzymes that confer drought tolerance in Carthamus tinctorius L. Additionally, melatonin causes increase in the amount of photosynthetic pigments, osmoprotectants and as such relative water content in Zea mays seedlings that progresses with increase in the overall development of the plant and a decline in ROS-mediated oxidative damage [107]. Melatonin contributes to 
regulation of $\mathrm{C}$ and $\mathrm{N}$ metabolism in a coordinated manner; thereby increases its ability of plants to survive under drought stress [108]. Transcriptomic studies of such plants revealed increase in the rate of photosynthesis, $\mathrm{N}$-assimilation, protein biosynthesis under drought stress conditions. The explants of shoot tips of cherry grown in vitro in medium having melatonin showed a 5-fold increase in proline level and 3 to 4 -fold enhancements in the carbohydrate content, suggesting osmoregulatory role of melatonin [109]. Over expressing SNAT and HIOMT enzymes of tomato during drought, the transgenic plants overcome stress following watering, on the other hand the wild type plants died. It is well-known that exogenous melatonin increases total chlorophyll content exposed to drought [110]. Cui et al. studied that exogenous melatonin in wheat seedling regulate water balance by reducing the MDA level and this reduction in MDA by melatonin is associated with elimination of adverse effect of stress that make intact grana lamella under drought [111]. Biosynthetic gene expression of apple MzSNAT5 in Arabidopsis promotes endogenous melatonin which ultimately improves the capacity for tolerance to drought [103]. Melatonin increases photosystem II efficiency in dark and light conditions in apple trees and alleviate the photo inhibition by drought stress, thus making the leaves more efficient in maintaining the higher $\mathrm{CO}_{2}$ assimilation and stomatal conductance [102]. Melatonin application enhanced the photosynthetic rate by decreasing the chlorophyll degradation and increases the activities of ROS-scavenging enzymes, and reversing the severe effects of water stress [36]. Melatonin increases the functioning of the stomata under drought exposure [77]. Melatonin downregulates an enzyme in ABA biosynthesis 9-cis-epoxycarotenoid dioxygenase (NCED), and upregulates two CYP707 monooxygenases, important enzymes involved in the metabolism of $\mathrm{ABA}$ on exposure to drought. The lower $\mathrm{H}_{2} \mathrm{O}_{2}$ and $\mathrm{ABA}$ content in melatonin grown plants increased stomatal performance reducing the drought conditions [77].

Melatonin application prominently caused stunted growth and enabled plants to maintain uptake fluxes and also abolished the adverse effects of drought on stomatal apertures, photosynthesis, and relative water content, and it nullify the oxidative burst [112]. Melatonin application increases nitrogen metabolism enzyme such as NR, NiR, GS, and GOGAT and uptake genes that show up-regulation in the leaves under drought stress and increase uptake, utilization and $N$-accumulation. It has been reported that melatonin $100 \mu \mathrm{M}$ modulate antioxidative in oat under 20\% PEG-6000 stress. Melatonin upregulates mitogenactivated protein kinases expression (MAPKs) Asmap1 and Aspk11, and the transcription factor (TF) genes on exposure to drought thereby enhancing the plant's tolerance [113]. Plants efficiently regulate water balance by up-regulating the melatonin synthesis genes expression MdTDC1, MdAANAT2, MdT5H4, and MdASMT1 under drought conditions. Its treatment in Malus maintains the water status under drought [77]. Melatonin increase photosynthesis by inhibiting stomatal closure, increasing absorption of light energy, and inducing photosynthetic electron transport and transcription enzymes, $\mathrm{CO}_{2}$ fixation was up regulated under drought [110]. Melatonin improves the water absorption in roots by regulating aquaporin channels and involved in stress mitigation [114]. Melatonin increased drought tolerance by increasing the cell turgor and water holding capacity [111]. Melatonin reduces the water deficiency by promoting antioxidants capacity and nitrate reductase in Lupinus terminis [115].

\subsection{Melatonin under Salt Stress}

Salinity is the most hazardous stress factor that reduces the crops production in the arid and semi-arid regions of the world [52,116,117]. A high level of salinity reduces plant growth, productivity, and seed germination, and affects the quality and quantity of the of the crop [118]. Salinity stress reduces growth attributes in the plant leaf area which then lowers the photosynthesis rate and ultimately lowers biomass production [117,119]. Exogenous application of melatonin in cotton plants relieves the negative impact salt stress [60]. Melatonin (exogenous source) was found enhancing the endogenous levels of melatonin, sugar, $\mathrm{K}^{+} / \mathrm{Na}^{+}$, and proline content thereby increasing the rate of germination of seeds dur- 
ing conditions of salt stress. Application of melatonin increases the weight (both fresh and dry) of rice seedlings and causes enhancement in the utilization of arginine, polyamines, and nitric oxide under condition of salt stress [120]. Melatonin was also found to enhance the ATP levels, besides increasing the activity of $\mathrm{H}^{+}$-pump [121]. Ke et al. studied the use of melatonin in minimizing the negative effects of salinity stress by accelerating polyamine metabolism and also suggested that enzyme activity can be increased that results in stimulating ROS scavenger antioxidant defenses in relation to salinity [122]. Zhou et al. found that photosynthetic process were triggered with melatonin by accelerating the protein biosynthesis and photosynthetic electron chain in tomato plants under salt stress [123]. Melatonin attenuated salt-induced decreases in relative water content, photosynthetic attributes, amino acid and antioxidant metabolism, and melatonin application improved plant performance and yield in plants [52]. Compared with the controls, application of melatonin demonstrated enhancement in the expression of antioxidant enzymes such as CAT1, APX, SOD1, Peroxiredoxin Q (PrxQ) and 2-cysteine peroxiredoxin, that resulted in an increase in the rate of photosynthesis and a subsequent decrease in oxidative damage in Phaseolus vulgaris (L.) grown under salt stress [124]. A similar effect of increased seed germination and growth of seedlings, antioxidants enzymes, along with reduction in oxidative damage was observed in Medicago sativa (L.) [125]. Melatonin enhanced salt tolerance by minimizing the sodium content in order to maintain $\mathrm{Na}^{+} / \mathrm{K}^{+}$homeostasis, it reduced lipid oxidation, and increased chlorophyll production. On the basis of metabolome profiles showing the abundances of metabolites in plants treated with salt plus metabolites. Endogenous melatonin and its intermediates having antioxidant functions indicate their role in alleviating the effect of salt stress in Oryza sativa [94]. Photosynthetic performance increased with melatonin under the coordinated application of salt and heat in tomato plants [15].

\subsection{Melatonin under Low Temperature Stress}

Low temperature stress negatively affects plant growth and productivity [36], which is responsible for crop loss throughout the world. Photosynthesis is the primary process affected by cold stress [126]. Cold stress reduces photosynthetic capacity, development of chloroplast, and causes a decline in chlorophyll fluorescence [56,127-129]. Melatonin supplementation in Solanum lycopersicum grown under cold stress helped the plant overcome damage caused by increased accumulation of ROS species, and in recovering the photosynthetic events to cope with the cold stress [130]. Different reports indicated the role of Melatonin in alleviating cold stress tolerance in Cucumis sativus, Triticum aestivum and Oryza sativa $[55,128,131]$ by increasing the germination rate, and in promoting survival under extreme cold conditions in Rhodiola crenulate (Hook. f. et Thomson) [132]. The protective role of melatonin studied in Vigna radiate (L.) meristem cells of root under chilling conditions has also been studied [133]. Arabidopsis plants grown with melatonin at $4{ }^{\circ} \mathrm{C}$ have a greater root length, height, and weight [134] and upregulated cold signaling gene expression increases cold tolerance in the plants [135]. Plants grown at $6{ }^{\circ} \mathrm{C}$ showing a 2.5 -fold increase in the content of melatonin when compare to plants grown at $24^{\circ} \mathrm{C}$ [87]. Melatonin application at $1 \mathrm{mM}$ enhanced antioxidant enzymes activity and improved plant growth and photosynthesis by minimizing oxidative stress in Triticum [128]. It has been observed that the reduction in proteins of PSII triggers the protective role of melatonin to PSII under cold stress [55]. The plants receiving melatonin enhanced production of $\mathrm{ABA}$, and both melatonin and $\mathrm{ABA}$ remove cold induced oxidative damage by reducing the oxidative stress and increasing the level of AsA, GSH, and SOD, CAT, APX, and GR. Melatonin increased the expression of several cold responsive genes such as $\mathrm{CBF}$ and cold regulated (COR) genes [136]. Application of melatonin at $5 \mathrm{~mol} \mathrm{~L}^{-1}$ helps to overcome oxidative damage caused by ROS due to an increase in the plant mineral element status and the transcript abundance of antioxidant-related genes as part of a mechanism to overcome cold stress [137]. Pre-soaking seed treatment and parental treatment with melatonin are effective ways for low temperature tolerance induction in wheat [138]. The rootstock of cucurbit 
species promotes melatonin accumulation in leaves that promote MeJA accumulation and provide tolerance against cold [53].

The photoinhibition was overcome by melatonin during chilling by promoting maximum quantum yield and the effective photochemical efficiency of PS II. It induces the expression of violaxanthin de-epoxidase, and its cofactor ascorbic acid was enhanced in Solanum lycopersicum [95]. Furthermore, melatonin protected PSII activities via inducing antioxidant metabolism in Oryza sativa [56]. Photosynthetic fluorescence parameters enhanced under cold stress when plants were treated with melatonin. There was alteration in the 46 metabolites studied such as arabinose, glucopyranose, mannose, maltose, and turanose which were greatly enhanced in Cynodon dactylon [96]. Supplementation of $1 \mu \mathrm{M}$ melatonin improves growth in Hordeum vulgare under cold stress [139]. In a study performed on Pistacia vera (L.) grown under cold stress, application of melatonin caused a significant decrease in the expression of oxidative stress biomarkers, with a subsequent decrease in sugar, proline, and GABA content [140]. Melatonin treatment enhances seed germination and prevents protein and lipid oxidation in embryonic cells of Capsicum annum and Zea mays, besides causing an increase in the antioxidant levels [141,142]. Turk and Genisel reported that application of melatonin in maize plays an important role in improving plant growth attributes and in protecting plants from oxidative damage via reduction in the ROS levels [143]. In litchi fruit subjected to chilling stress, treatment by exogenous melatonin prevented discoloration of pericarp by increasing the anthocyanin levels and inducing proline accumulation [144]. In Prunus salicina (Lindl.) melatonin, pretreatment of fruits caused enhancement in the levels of spermine, spermidine, and putrescine via regulation of the SAMDC and TGase activities [145]. It has also been observed that melatonin increases the shelf life of sweet cherry fruits and upgrades the quality of fruit by regulation expression of different genes in Prunus avium (L.) [146].

\subsection{Melatonin under Heavy Metal Stress}

Due to the setup of industries and factories, there is increased contamination by heavy elements in soil agriculture that reduce crop productivity and economy $[9,10]$. The Addition of heavy metals through various sources inhibits photosynthesis, alters nitrogen metabolism, growth, and yield $[147,148]$. The role of melatonin in heavy metal contaminated soil has been studied in the recent years $[48,149]$. Melatonin mitigates copper toxicity by increasing the growth characteristics and increase the mitochondrial electron transport chain resulting in the production of fewer free radical [150], and foliar application of melatonin provides cadmium tolerance in Nicotiana tabacum and decreases the accumulation of metal $[41,58]$. Heavy metal, such as $\mathrm{Cd}, \mathrm{Zn}$, and Pb-induced oxidative stress is reduced by applying $200 \mu \mathrm{M}$ exogenous melatonin by inducing the SOD activity in Exophiala pisciphila (McGinnis \& Ajello) [151]. Nawaz et al., while studying Citrullus lanatus plants exposed to vanadium treated with melatonin, enhanced the total chlorophyll content and associated chlorophyll genes in leaves [18]. Supplementation of melatonin reverses $\mathrm{Cd}$ toxicity by increasing the biomass and antioxidant metabolism involved in phytochelatin biosynthesis in Solanum lycopersicum [152] as well as minimizes metal toxicity via improving the uptake of key nutrients such as nitrogen, phosphorus, and sulfur, and improving cell metabolism [48]. Upregulating RsMT1 in radish confers Cd tolerance [153]. Foliar application of melatonin at $100 \mu \mathrm{mol} \mathrm{L}^{-1}$ is more effective in slowing the senescence and improves seedling biomass under Cd stress in strawberry [154].

Melatonin promotes plant growth by developing antioxidant systems and alleviating heavy metal toxicity by employing its chelating property that helps in reducing their accumulation at the rhizospheric surface [155]. Lower concentrations of melatonin show apositive impact on $\mathrm{Cd}$ tolerance by promoting photosynthesis, growth, and maintaining relative water content and stomatal conductance through increasing proline metabolism in Malva parviflora (L.) [156], and preventing metal toxicity by inducing defense systems [157]. Melatonin decreases the methylation of upregulated genes RsAPX2, RsPOD52, and RsGST and scavenges lead-induced ROS in radish [158]. In a study on Indian rice cultivars, 
exogenous application of melatonin overcome arsenic stress by increasing the levels of organic acids and by upregulating the expression of respiratory and sugar metabolism enzymes [159]. In Melissa Officinalis (L.), plants exogenous melatonin application helps to reduce oxidative damage via antioxidant defense mechanisms and, as such, contribute to a better tolerance to $\mathrm{Zn}$ and $\mathrm{Cd}$ [160]. Improving plant growth and minimizing oxidative damage via development of the antioxidant system on application of melatonin exogenously contributes to increasing the yield among chromium stressed Triticum aestivum [161]. Melatonin application in Brassica napus helps to overcome the effect of $\mathrm{Al}$ and $\mathrm{Cd}$ stress by causing enhancement in the antioxidant armor and in overall plant growth [162]. Application of melatonin helps in reducing the uptake of $\mathrm{Pb}$ from the soil; thereby contributing to enhancement in the plant biomass, GSH content in leaves, and antioxidant defense in Carthamus tinctorius [163]. A recent study reported an improvement in regulating the enzymes of photosynthesis that contribute to growth in Eruca vesicaria (L.) plants growing under $\mathrm{Pb}$ stress [164]. Melatonin (50 or $100 \mu \mathrm{M})$ attributes to physiological parameters of leaves and overall growth. Its decrease in ROS and triggering of NO production contributes significantly to overcoming growth of Triticum aestivum grown under Cd-stress [71].

\subsection{Melatonin under Herbicide Stress}

Herbicides are applied in crop fields to increase their yield. These herbicides remain in the soil for a longtime affecting the next crop or even the plants used as green manure. Presently, these herbicides are chemical agents mostly employed for the check growth and development of weeds in the agricultural field and their use in high concentration inhibits physiological function in plants [165]. Use of commonly used herbicides in agriculture effects both the target and other associated plants [166,167]. Their use in high concentrations inhibits plant physiology [165]. Use of herbicides such as pendimethalin on Foeniculum vulgare (Mill.) leaves [168]; chevalier in Triticum aestivum cultivars [169] and in Vicia faba (L.), cause a decrease in photosynthesis [170]. Application of a $10 \mathrm{mM}$ dose of glyphosate reduced photosynthesis-related proteins in Zea mays [171]. In Triticum aestivum, a reduction in chlorophyll content was reported with $300 \mu \mathrm{gkg}^{-1}$ chlorimuron-ethyl [172]. Numerous Research publications have reported the role of melatonin in minimizing the adverse effects of herbicides applied to plants. Kaya and Doganlar studied the effects of the herbicide pendimethaline (Pend) and drought stress on pepper. Melatonin at $50 \mu \mathrm{M}$ alleviated adverse effects of 10\% PEG and herbicide pend $(8,16$ and $32 \mathrm{mM})$ stresses by promoting the antioxidant enzyme, relative water content, photosynthetic pigments, proline, and mRNA levels [92]. Melatonin increased P5CS expression and the enzymes involved in proline biosynthesis, on exposure to Methyl viologen [173]. Melatonin pretreated seeds decreased oxidative stress in growing seedlings. This beneficial effect was reported in leaves where their reduced accumulation of superoxide anion and protection of photosynthetic attributes under paraquat in Pisum sativum [93]. Liu et al., reported in Cucumus sativus that melatonin addition could relieve oxidative stress induced by imidacloprid via its degradation through increased antioxidants such as AsA/DHA, GSH/GSSG ratios, MDHAR, DHAR, and GR, maintaining the ascorbic acid-glutathione cycle [174]. Growth of Ipomoea batatas (L.), in MS media supplemented with a combination of bentazon and melatonin helped in reducing the effect of bentazon [175].

\subsection{Melatonin under Temperature (High) Stress}

Environmental stressors, such as extreme temperatures, can cause severe damage to plants. High temperatures hinder plant growth and yield, and thus pose a threat to growth potential and food security $[26,57,176,177]$. Heat stress changes the stability of proteins and cause changes on the enzyme level, as well as biomolecules which are associated with the generation of ROS $[27,78]$. Higher temperatures disrupt the fluidity of the membrane and activities of enzymes [79], leading to a reduction in photosynthesis, growth, and yield $[27,40]$. 
High temperature application increases the level of melatonin in Solanum lycopersicum [57] suggesting melatonin's role in the defense against heat stress. Rising temperatures increase melatonin levels suggests its power to increase heat tolerance in green micro-algae Ulva sp. [178]. Supplementation of melatonin reverses the ill effect of high temperature on photosensitive and thermosensitive Phacelia tanacetifolia (Benth.) seeds [179]. Melatonin exposure enhanced the percentage of germination in heat stressed seeds by 60\% in Arabidopsis thaliana because of its strong antioxidant metabolism activity [180]. Melatonin deficiency at the endogenous level induces oxidative stress as revealed by high MDA concentration and high electrolyte leakage in tomato plant leaves grown in high temperatures. Furthermore, there is a reduction in ascorbate peroxidase and catalase activity that play an important role in thermotolerance [181]. Exogenous application of melatonin $(100 \mu \mathrm{M})$ helps in increasing the levels of endogenous melatonin, which contributes to enhancement in the expression of photosynthesis-related genes and, as such, activity of PSII in tomato plants [57]. Melatonin applied to Lolium perenne L. not only increased melatonin and cytokinin endogenously, but also reduced the concentration of ABA under heat stress [65], protected proteins from misfolding, and oxidizing under heat stress in tomato plants [182]. Melatonin maintains proper redox signaling preventing oxidative stress in Cucumis sativus [183]. Reports show that melatonin increases antioxidant enzyme activity in tomato pollen on exposure to heat stress [184]. Exogenous melatonin more effectively increased the biosynthesis of enzymes related to nitrogen metabolism, nitrate content, and restricting the ammonium accumulation in cucumber seedlings at high temperatures, thus providing resistance [185].

Foliar application of melatonin at $10 \mu \mathrm{M}$ reduced heat induced photoinhibition by over expressing the $N$-acetyl serotonin methyltransferase (ASMT) gene. This was achieved by minimizing the electrolyte leakage through enhancing the photosystem II and high temperature tolerance in tomato seedlings by increasing the antioxidant defense system [182]. Table 1 shows abiotic stress-induced changes on exposure to melatonin in plants. Mechanisms of abiotic stress induce oxidative stress and the role of melatonin in overcoming the stress is shown in Figure 2.

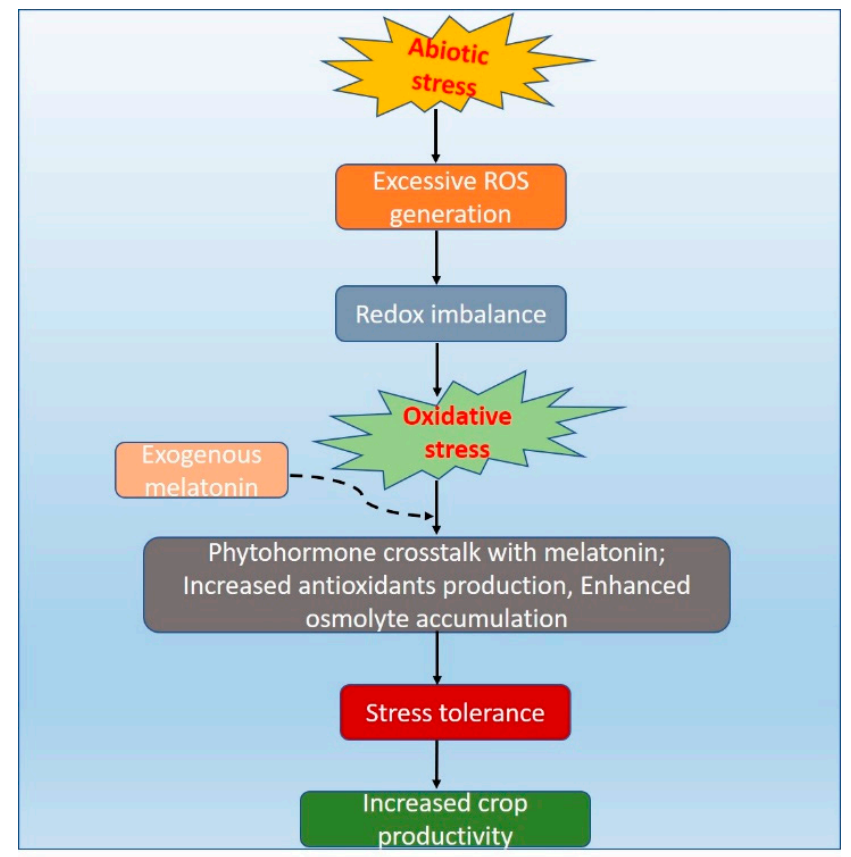

Figure 2. Role of melatonin in overcoming abiotic stress.

\section{Melatonin Crosstalk with Phytohormones under Abiotic Stresses}

Research has shown that coordination between melatonin and $\mathrm{NO}$ as a signaling molecule performs many actions in plants such as growth and abiotic stress tolerance [186]. 
Metabolites that are enhanced are carbohydrates such as fructose, galactose, glucose, sucrose, and proline that are important components of osmotic adaptation in abiotic stress response [96]. The regulation of rice melatonin-related genes by jasmonic acid (JA), abscisic acid (ABA) in response to numerous stresses demonstrate the mechanism of crosstalk of $\mathrm{ABA}$ and JA. Melatonin is reported to enhance the contents of polyamine by increasing the metabolic flow from arginine and methionine to polyamines. Melatonin also decreased off salt-induced degradation of polyamines [122]. SA and melatonin share the common biosynthetic precursor and reduce the damage caused by water deficits. The proper utilization of these molecules is responsible for promoting plant development and crop yield [58]. Melatonin upregulates the expression of genes in GA biosynthesis, downregulates important genes in $\mathrm{ABA}$ biosynthesis, and upregulates $\mathrm{ABA}$ 8'-hydroxylase genes, which mediate the changes in ABA and GA levels during germination [49]. MeJA increases the accumulation of melatonin, causing the formation of a self-amplifying feedback loop that is involved in cold tolerance [53] as well as increasing the biosynthesis of metabolic enzymes of auxins, brassinosteroids, and NO generation, and its associated expression of genes that have a role in defense [149]. Salt stress recovers amino acid constituents by applying melatonin to the roots, except Proline on the 8th day. After 8 days, the highest value for glutamic acid and lowest value was seen for cystine in salt treated plants exposed to melatonin. A reduction in ABA content and an increase in the content of salicylic acid is studied in salt treated plants with melatonin [52]. Melatonin promotes endogenous melatonin and inhibits the NCED1, an ABA synthesis gene, as well as up-regulates ABA catabolic genes, $\mathrm{ABA} 8 \mathrm{ox} 1$ and $\mathrm{ABA} 8 \mathrm{ox} 3$, decreasing the accumulation of ABA by promoting the stomatal reopening [53]. Melatonin has similar actions to those of indole-3 acetic acid [73] in that it induces endogenous NO that regulates transcription factors and maintains redox homeostasis involved in stress tolerance [187]. Exogenous application of melatonin at $0.1 \mu \mathrm{M}$ melatonin increased root elongation, increased endogenous IAA levels in the root, while as treatment with $100 \mu \mathrm{M}$ indicating inhibition on root growth had no effect on IAA in Brassica juncea [34]. Melatonin under drought stress induces the function of stomata by maintaining the balance of water and downregulating the ABA pathway in Malus hupehensis [77]. Melatonin and salicylic acid are involved in abiotic stress tolerance as these both share common biosynthetic pathways [58]. Melatonin increases GA content but reduces ABA content when exposed to high temperature stress highlighting it's antagonistic role in the developmental processes [57]. The crosstalk of melatonin with different signaling molecules revealed a relation in their biosynthetic pathways.

It has been reported in Cucumis melo (L.) that melatonin regulates linoleic acid metabolism and promotes root development. Melatonin interacts with Jasmonic acid and inhibits the expression of LOX-related genes to relieve against oxidative stress [188]. Melatonin and NO interacts with each other in inducing plant growth and develops tolerance to abiotic stress through inducing the antioxidant system [189]. Melatonin induces either NO production or its scavenging activity, and enhances the activity of NOS-like proteins [190,191]. As revealed by the RNA sequencing method, melatonin induced the seed germination in correlation with auxin, gibberellin (GA), and abscisic acid (ABA) in Arabidopsis [192]. Melatonin is involved in inducing seed germination by counteracting $\mathrm{ABA}$ to maintain the ABA/ $\mathrm{GA}_{3}$ balance [193]. Exogenous melatonin also induces the production of endogenous $\mathrm{NO}$ which antagonizes ethylene biosynthesis and, henceforth, delays senescence [194]. Melatonin, along with $\mathrm{H}_{2} \mathrm{~S}$, helps in mitigating high temperature stress by improving photosynthetic attributes and carbohydrate metabolism [64]. Besides reducing accumulation of indole-3-acetic acid, melatonin $(20 \mu \mathrm{M})$ application in Oryza sativa grown under fluoride stress hinders fluoride uptake and alters the phytohormone homeostasis [72]. ABA enhanced relative water content of drought treated leaves by minimizing the water loss, melatonin was found increasing it by inducing the water uptake efficiency. Additionally, ABA and melatonin were found capable of modulating activity of superoxide dismutase under drought stress [195]. Melatonin application in the rhizosphere imparts greater protection than its foliar application under conditions of drought stress. 
Concentrations of salicylic acid and jasmonic acid in the root zone were significantly high for foliar application of melatonin in soybean [196]. Increased photosynthesis, reduction of $\mathrm{ABA}$, and lowering of ROS induced by drought are key attributes of the role played by melatonin.

\section{Photosynthetic Regulation by Melatonin under Abiotic Stress}

Photosynthesis is the process in plants which is restricted to the green parts of plants i.e., leaves [197]. Photosynthesis controls numerous metabolic processes and converts light energy into chemical energy $[198,199]$. Both the light and dark reactions of photosynthesis occur in chloroplast, which is highly sensitive to abiotic stresses. It has been shown that melatonin application increased photosynthesis under abiotic stress [56,95]. Melatonin improves photosynthesis and maintains redox status in a dose-dependent manner in Brassica juncea [200]. Recently, it has been studied that melatonin triggers endogenous melatonin, through the Phyto-melatonin receptor CAND2/PMTR1. An increase in endogenous melatonin levels then leads to an increase in photosynthesis, and the promotion of the biosynthesis of hormones, nitric oxide, and polyamine [48,201]. However, very recently, it has been reported that the application of melatonin reduced ROS production by creating a constant flow of electrons, thereby maintaining the abundance of $P s b O$ and $D 1$ for improving the repair of photosystem II [202]. Melatonin plays a crucial role in photosynthesis and photoprotection [104]. Melatonin induces chlorophyll content and biomass, and increases the efficiency of the reaction centers of photosystem II in the macroalga Ulva sp. under salt stress [178] and in the freshwater Chara australis (L.) [203]. Generally, plants under stress conditions close their stomata to prevent water loss, so affecting stomatal conductance and reducing photosynthesis [8]. However, melatonin increases the stomatal function and permits the reopening of the stomata in plants treated with salt [91], and hence, improves the net photosynthetic rate of plants under salt stress. Melatonin treatment improved the Fv/Fm by promoting the chlorophyll biosynthesis under salt stress [49]. Melatonin expressed photosynthesis-related genes under salt stress and had a positive impact on glucose and fatty acid metabolism, and ascorbic acid synthesis in Cynodon dactylon [89]. Moreover, melatonin enhanced the transcription level of photosynthesis-related genes under salt stress and protected the photosynthetic apparatus [88]. Reports suggest that, under drought stress, melatonin can directly scavenge ROS and improve the antioxidant activity of enzymes to remove the oxidative damage induced by drought stress in cells [36]. Recent work on melatonin has also suggested the beneficial role of melatonin in improving plant photosynthetic rates under water stress [204] by inhibiting chlorophyll degradation in Barley roots [205].

The photosynthetic performance of plants enhanced by melatonin protects chlorophyll molecules and the chloroplast ultrastructure of plants treated with drought stress [206,207] and regulates photosynthesis by expressing the key gene involved in chlorophyll metabolism in Carya cathayensis (L.) [208]. The increased leaf area in plants treated with melatonin was also involved in improving photosynthesis under water-deficit conditions in Coffea arabica (L.) [209]. Melatonin in mesophyll cells maintain the cell turgor and water balance to induce the stomatal conductance and chlorophyll fluorescence in Medicago sativa [210]. Melatonin induces the pathway of carbon fixation by modulating the expression of important enzymes [83]. The ROS disrupts PSII due to oxidative stress on the thylakoid membrane [211] and the use of melatonin reduces ROS by preventing the damage to thylakoid and chloroplast membranes in Fagopyrum tataricum (L.) [212]. Melatonin induces the activity of Calvin cycle enzymes and protects PSII proteins under cold and drought stress, respectively $[50,56]$. Melatonin recovers gas exchange and chlorophyll content on exposure to salt stress in Brassica juncea [50,52].

\section{Conclusions}

Abiotic stresses cause various problems at the physiological and molecular levels in plants, resulting in a significant reduction of productivity worldwide. Melatonin is a 
bioactive compound in a number of vascular plants. The aim of the current review was to collect the research completed in the recent year on melatonin under different abiotic stresses. There has been a surge in research publications on this topic in the last few years. Crosstalk between auxin and melatonin should be focused on more as both share the common precursor: tryptophan. Exogenous melatonin recovers plant vigour and growth under different stresses. Based on the literature in the text, it may be concluded that melatonin is involved in combating the numerous stresses via regulating the antioxidant metabolism and protecting the photosynthetic machinery. Increased photosynthesis makes it easier to improve the crop productivity and thus address the key issue of food insecurity around the world. As abiotic stress reduces the quality and yield of crops, the application of melatonin at a field level can be useful from an agronomic point of view. Future research is required to know the genetic mechanisms and metabolic pathways involved during recovery under stress conditions on exposure to melatonin. Future studies using phytohormone mutants are needed to clarify how melatonin functions with various phytohormones in different physiological processes and crosstalk with more signaling molecules is to be elucidated. Melatonin was shown to influence field crops and also has been proven beneficial in increasing the yield of crops and nutraceutical values. Melatonin-rich plants could be used to recover soil contaminated with chemicals and improve the phytoremediation practices. Detailed research should be conducted on molecular aspects using Omics approaches to figure out gene regulating physiological, biochemical, and anatomical features in response to melatonin under abiotic stress. Melatonin is a nontoxic biodegradable molecule which could be used for promoting organic farming [213]. Use of synthetic melatonin, a cheap compound, or phytomelatonin-rich extracts, should be a key strategy in improving the plant tolerance against abiotic stress [214,215].

Author Contributions: Conceptualization, A.T.J. and M.A.; writing—original draft preparation, A.R. and A.K.M.; writing-review and editing, T.S.P.; M.H.; A.T.J. and M.A.; Data for Table, A.F. and T.S.P.; Figure preparation, A.T.J. and M.A.; supervision, A.T.J. and M.A.; project administration, M.A.; funding acquisition, A.K.M. and M.A. All authors have read and agreed to the published version of the manuscript.

Funding: This research was funded by UGC and SERB New Delhi, India, with grant numbers 30-441/2018 and SRG/2019/001766.

Institutional Review Board Statement: Not Applicable.

Informed Consent Statement: Not Applicable.

Data Availability Statement: Not Applicable.

Acknowledgments: Authors acknowledge all colleagues whose comments helped in increasing the readability of contents and information given under different headings.

Conflicts of Interest: The authors declare no conflict of interest.

\section{References}

1. Waqas, M.A.; Khan, I.; Akhter, M.J.; Noor, M.A.; Ashraf, U. Exogenous application of plant growth regulators (PGRs) induces chilling tolerance in short-duration hybrid maize. Environ. Sci. Pollut. Res. 2017, 24, 11459-11471. [CrossRef]

2. Vaughan, M.M.; Block, A.; Christensen, S.A.; Allen, L.H.; Schmelz, E.A. The effects of climate change associated abiotic stresses on maize phytochemical defenses. Phytochem. Rev. 2017, 17, 37-49. [CrossRef]

3. Zafar, S.A.; Noor, M.A.; Waqas, M.A.; Wang, X.; Shaheen, T.; Raza, M.; Rahman, M.U. Temperature Extremes in Cotton Production and Mitigation Strategies. Cercet. Agron. Mold. (Agron. Res. Mold.) 2018, 183, 65-91. [CrossRef]

4. Dos Reis, S.P.; Lima, A.M.; De Souza, C.R.B. Recent Molecular Advances on Downstream Plant Responses to Abiotic Stress. Int. J. Mol. Sci. 2012, 13, 8628-8647. [CrossRef] [PubMed]

5. Nadeem, M.; Li, J.; Wang, M.; Shah, L.; Lu, S.; Wang, X.; Ma, C. Unraveling field crops sensitivity to heat stress: Mechanisms, approaches, and future prospects. Agronomy 2018, 8, 128. [CrossRef]

6. Nadeem, M.; Li, J.; Yahya, M.; Wang, M.; Ali, A.; Cheng, A.; Wang, X.; Ma, C. Grain Legumes and Fear of Salt Stress: Focus on Mechanisms and Management Strategies. Int. J. Mol. Sci. 2019, 20, 799. [CrossRef] [PubMed] 
7. Bhat, M.A.; Kumar, V.; Bhat, M.A.; Wani, I.A.; Dar, F.L.; Farooq, I.; Bhatti, F.; Koser, R.; Rahman, S.; Jan, A.T. Mechanistic Insights of the Interaction of Plant Growth-Promoting Rhizobacteria (PGPR) With Plant Roots Toward Enhancing Plant Productivity by Alleviating Salinity Stress. Front. Microbiol. 2020, 11, 1952. [CrossRef]

8. Bhat, M.A.; Mir, R.A.; Kumar, V.; Shah, A.A.; Zargar, S.M.; Rahman, S.; Jan, A.T. Mechanistic insights of CRISPR /Cas-mediated genome editing towards enhancing abiotic stress tolerance in plants. Physiol. Plant. 2021, 172, 1255-1268. [CrossRef] [PubMed]

9. Asgher, M.; Khan, M.I.R.; Anjum, N.A.; Khan, N.A. Minimising toxicity of cadmium in plants: Role of plant growth regulators. Protoplasma 2015, 252, 399-413. [CrossRef]

10. Thao, N.P.; Khan, M.I.R.; Thu, N.B.A.; Hoang, X.L.T.; Asgher, M.; Khan, N.A.; Tran, L.-S.P. Role of Ethylene and Its Cross Talk with Other Signaling Molecules in Plant Responses to Heavy Metal Stress. Plant Physiol. 2015, 169, 73-84. [CrossRef]

11. Sharma, A.; Zhesng, B. Melatonin mediated regulation of drought stress: Physiological and molecular aspects. Plants 2019, 8, 190. [CrossRef]

12. Ahmed, S.; Kouser, S.; Asgher, M.; Gandhi, S.G. Plant aquaporins: A frontward to make crop plants drought resistant. Physiol. Plant. 2021, 172, 1089-1105. [CrossRef]

13. Mantri, N.; Patade, V.; Penna, S.; Ford, R.; Pang, E. Abiotic Stress Responses in Plants: Present and Future. In Abiotic Stress Responses in Plants; Springer: Berlin/Heidelberg, Germany, 2011; pp. 1-19.

14. Canter, L.W. Environmental Impact of Agricultural Production Activities; Taylor \& Francis Group: Abingdon, UK, 2018.

15. Martinez, V.; Nieves-Cordones, M.; Lopez-Delacalle, M.; Rodenas, R.; Mestre, T.C.; Garcia-Sanchez, F.; Rubio, F.; Nortes, P.A.; Mittler, R.; Rivero, R.M. Tolerance to stress combination in tomato plants: New insights in the protective role of melatonin. Molecules 2018, 23, 535. [CrossRef]

16. Zörb, C.; Geilfus, C.; Dietz, K. Salinity and crop yield. Plant Biol. 2018, 21, 31-38. [CrossRef]

17. Stael, S.; Rocha, A.G.; Robinson, A.J.; Kmiecik, P.; Vothknecht, U.; Teige, M. Arabidopsis calcium-binding mitochondrial carrier proteins as potential facilitators of mitochondrial ATP-import and plastid SAM-import. FEBS Lett. 2011, 585, 3935-3940. [CrossRef]

18. Nomura, H.; Komori, T.; Uemura, S.; Kanda, Y.; Shimotani, K.; Nakai, K.; Furuichi, T.; Takebayashi, K.; Sugimoto, T.; Sano, S.; et al. Chloroplast-mediated activation of plant immune signalling in Arabidopsis. Nat. Commun. 2012, 3, 926. [CrossRef]

19. Borges, A.A.; Jiménez-Arias, D.; Expósito-Rodríguez, M.; Sandalio, L.M.; Pérez, J.A. Priming crops against biotic and abiotic stresses: MSB as a tool for studying mechanisms. Front. Plant Sci. 2014, 5, 642. [CrossRef]

20. Balmer, A.; Pastor, V.; Gamir, J.; Flors, V.; Mauch-Mani, B. The "prime-ome": Towards a holistic approach to priming. Trends Plant. Sci. 2015, 20, 443-452. [CrossRef]

21. Balmer, A.; Pastor, V.; Glauser, G.; Mauch-Mani, B. Tricarboxylates induce defense priming against bacteria in Arab. Thaliana. Front. Plant Sci. 2018, 9, 1-15. [CrossRef] [PubMed]

22. Westman, S.M.; Kloth, K.J.; Hanson, J.; Ohlsson, A.B.; Albrectsen, B.R. Defence priming in Arabidopsis—a Meta-Analysis. Sci. Rep. 2019, 9, 13309. [CrossRef]

23. Fleming, T.R.; Fleming, C.C.; Levy, C.C.B.; Repiso, C.; Hennequart, F.; Nolasco, J.B.; Liu, F. Biostimulants enhance growth and drought tolerance in Arabidopsis thaliana and exhibit chemical priming action. Ann. Appl. Biol. 2019, 174, 153-165. [CrossRef]

24. Du Jardin, P. Plant biostimulants: Definition, concept, main categories and regulation. Sci. Hortic. 2015, 196, 3-14. [CrossRef]

25. Yakhin, O.I.; Lubyanov, A.A.; Yakhin, I.A.; Brown, P.H. Biostimulants in Plant Science: A Global Perspective. Front. Plant Sci. 2017, 7, 2049. [CrossRef] [PubMed]

26. Iqbal, N.; Umar, S.; Khan, N.A.; Corpas, F.J. Crosstalk between abscisic acid and nitric oxide under heat stress: Exploring new vantage points. Plant Cell Rep. 2021, 40, 1429-1450. [CrossRef]

27. Iqbal, N.; Umar, S.; Khan, N.; Corpas, F. Nitric Oxide and Hydrogen Sulfide Coordinately Reduce Glucose Sensitivity and Decrease Oxidative Stress via Ascorbate-Glutathione Cycle in Heat-Stressed Wheat (Triticum aestivum L.) Plants. Antioxidants 2021, 10, 108. [CrossRef]

28. Paredes, S.D.; Korkmaz, A.; Manchester, L.C.; Tan, D.-X.; Reiter, R.J. Phytomelatonin: A review. J. Exp. Bot. 2008, 60, 57-69. [CrossRef]

29. Back, K.; Tan, D.-X.; Reiter, R.J. Melatonin biosynthesis in plants: Multiple pathways catalyze tryptophan to melatonin in the cytoplasm or chloroplasts. J. Pineal Res. 2016, 61, 426-437. [CrossRef]

30. De la Puerta, C.; Carrascosa-Salmoral, M.P.; García-Luna, P.P.; Lardone, P.J.; Herrera, J.L.; Fernández-Montesinos, R.; Guerrero, J.M.; David, P. Melatonin is a phytochemical in olive oil. Food Chem. 2007, 104, 609-612. [CrossRef]

31. Wang, R.; Yang, X.; Xu, H.; Li, T. Research progress of melatonin biosynthesis and metabolism in higher plants. Plant. Physiol. J. 2016, 52, 615-627.

32. Arnao, M.B.; Ruiz, J.H. Growth activity, rooting capacity, and tropism: Three auxinic precepts fulfilled by melatonin. Acta Physiol. Plant. 2017, 39, 127. [CrossRef]

33. Van Tassel, D.L.; Roberts, N.; Lewy, A.; O’Neill, S.D. Melatonin in plant organs. J. Pineal Res. 2001, 31, 8-15. [CrossRef]

34. Chen, Q.; Qi, W.-B.; Reiter, R.J.; Wei, W.; Wang, B.-M. Exogenously applied melatonin stimulates root growth and raises endogenous indoleacetic acid in roots of etiolated seedlings of Brassica juncea. J. Plant. Physiol. 2009, 166, 324-328. [CrossRef] [PubMed]

35. Uchendu, E.E.; Shukla, M.R.; Reed, B.M.; Saxena, P.K. Melatonin enhances the recovery of cryopreserved shoot tips of American elm (Ulmus americana L.). J. Pineal Res. 2013, 55, 435-442. [CrossRef] [PubMed] 
36. Zhang, N.; Zhao, B.; Zhang, H.J.; Weeda, S.; Yang, C.; Yang, Z.C.; Guo, Y.D. Melatonin promotes water-stress tolerance, lateral root formation, and seed germination in cucumber (Cucumis sativus L.). J.PinealRes. 2013, 54, 15-23. [CrossRef] [PubMed]

37. Van Tassel, D.L.; Roberts, N.J.; O'Neill, S.D. Melatonin from higher plants: Isolation and identification of N-acetyl-5methoxytryptamine. Plant Physiol. 1995, 108, 101.

38. Murch, S.J.; Krishna Raj, S.; Saxena, P.K. Tryptophan is a precursor for melatonin and serotonin biosynthesis in in vitro regenerated St. John's wort (Hypericum perforatum L. cv. Anthos) plants. Plant Cell Rep. 2000, 19, 698-704. [CrossRef]

39. Ehardeland, R. Melatonin in Plants-Diversity of Levels and Multiplicity of Functions. Front. Plant Sci. 2016, 7, 198. [CrossRef]

40. Nawaz, M.A.; Huang, Y.; Bie, Z.; Ahmed, W.; Reiter, R.J.; Niu, M.; Hameed, S. Melatonin: Current status and future perspectives in plant science. Front. Plant Sci. 2016, 6, 1230. [CrossRef]

41. Sun, C.; Liu, L.; Wang, L.; Li, B.; Jin, C.; Lin, X. Melatonin: A master regulator of plant development and stress responses. J. Integr. Plant. Biol. 2020, 63, 126-145. [CrossRef]

42. Fan, J.; Xie, Y.; Zhang, Z.; Chen, L. Melatonin: A Multifunctional Factor in Plants. Int. J. Mol. Sci. 2018, 19, 1528. [CrossRef]

43. Hernández-Ruiz, J.; Arnao, M.B. Relationship of Melatonin and Salicylic Acid in Biotic/Abiotic Plant Stress Responses. Agronomy 2018, 8, 33. [CrossRef]

44. Park, S.; Lee, K.; Kim, Y.-S.; Back, K. Tryptamine 5-hydroxylase-deficient Sekiguchi rice induces synthesis of 5-hydroxytryptophan and $\mathrm{N}$-acetyltryptamine but decreases melatonin biosynthesis during senescence process of detached leaves. J. Pineal Res. 2011, 52, 211-216. [CrossRef] [PubMed]

45. Arnao, M.B.; Ruiz, J.H. Melatonin and its relationship to plant hormones. Ann. Bot. 2017, 121, 195-207. [CrossRef] [PubMed]

46. Ahn, H.R.; Kim, Y.-J.; Lim, Y.J.; Duan, S.; Eom, S.H.; Jung, K.-H. Key Genes in the Melatonin Biosynthesis Pathway with Circadian Rhythm Are Associated with Various Abiotic Stresses. Plants 2021, 10, 129. [CrossRef] [PubMed]

47. Posmyk, M.M.; Janas, K.M. Melatonin in plants. Acta Physiol. Plant. 2009, 31, 1. [CrossRef]

48. Arnao, M.B.; Hernández-Ruiz, J. Melatonin: A new plant hormone and/or a plant master regulator? Trends Plant. Sci. 2019, 24, 38-48. [CrossRef]

49. Li, J.; Liu, J.; Zhu, T.; Zhao, C.; Li, L.; Chen, M. The Role of Melatonin in Salt Stress Responses. Int. J. Mol. Sci. 2019, $20,1735$. [CrossRef]

50. Sadak, M.S.; Abdalla, A.M.; Elhamid, E.M.A.; Ezzo, M.I. Role of melatonin in improving growth, yield quantity and quality of Moringa oleifera L. plant under drought stress. Bull. Natl. Res. Cent. 2020, 44, 1-13. [CrossRef]

51. Weeda, S.; Zhang, N.; Zhao, X.; Ndip, G.; Guo, Y.; Buck, G.A.; Fu, C.; Ren, S. Arabidopsis Transcriptome Analysis Reveals Key Roles of Melatonin in Plant Defense Systems. PLoS ONE 2014, 9, e93462. [CrossRef]

52. Park, H.-S.; Kazerooni, E.A.; Kang, S.-M.; Al-Sadi, A.M.; Lee, I.-J. Melatonin Enhances the Tolerance and Recovery Mechanisms in Brassica juncea (L.) Czern. Under Saline Conditions. Front. Plant Sci. 2021, 12, 593717. [CrossRef]

53. Li, H.; Guo, Y.L.; Lan, Z.; Kai, X.; Chang, J.J.; Ahammed, G.J.; Ma, J.X.; Wei, C.; Zhang, X. Methyl jasmonate mediates melato-nininduced cold tolerance of grafted watermelon plants. Hortic. Res. 2021, 8, 57. [CrossRef] [PubMed]

54. Ahmad, S.; Kamran, M.; Zhou, X.; Ahmad, I.; Meng, X.; Javed, T.; Iqbal, A.; Wang, G.; Su, W.; Wu, X.; et al. Melatonin improves the seed filling rate and endogenous hormonal mechanism in grains of summer maize. Physiol. Plant. 2020, 172, 1059-1072. [CrossRef] [PubMed]

55. Posmyk, M.M.; Bałabusta, M.; Wieczorek, M.; Sliwinska, E.; Janas, K.M. Melatonin applied to cucumber (Cucumis sativusL.) seeds improves germination during chilling stress. J. Pineal Res. 2009, 46, 214-223. [CrossRef]

56. Han, Q.-H.; Huang, B.; Ding, C.-B.; Zhang, Z.-W.; Chen, Y.-E.; Hu, C.; Zhou, L.-J.; Huang, Y.; Liao, J.-Q.; Yuan, S.; et al. Effects of Melatonin on Anti-oxidative Systems and Photosystem II in Cold-Stressed Rice Seedlings. Front. Plant Sci. 2017, 8, 785. [CrossRef] [PubMed]

57. Jahan, M.S.; Shu, S.; Wang, Y.; Hasan, M.; El-Yazied, A.A.; Alabdallah, N.M.; Hajjar, D.; Altaf, M.A.; Sun, J.; Guo, S. Melatonin Pretreatment Confers Heat Tolerance and Repression of Heat-Induced Senescence in Tomato Through the Modulation of ABAand GA-Mediated Pathways. Front. Plant Sci. 2021, 12, 381. [CrossRef]

58. Wang, M.; Duan, S.; Zhou, Z.; Chen, S.; Wang, D. Foliar spraying of melatonin confers cadmium tolerance in Nicotiana tabacum L. Ecotoxicol. Environ. Saf. 2018, 170, 68-76. [CrossRef]

59. Feng, Y.; Fu, X.; Han, L.; Xu, C.; Liu, C.; Bi, H.; Ai, X. Nitric Oxide Functions as a Downstream Signal for Melatonin-Induced Cold Tolerance in Cucumber Seedlings. Front. Plant Sci. 2021, 12, 1432. [CrossRef]

60. Chen, L.; Liu, L.; Lu, B.; Ma, T.; Jiang, D.; Li, J.; Zhang, K.; Sun, H.; Zhang, Y.; Bai, Z.; et al. Exogenous melatonin promotes seed germination and osmotic regulation under salt stress in cotton (Gossypium hirsutum L.). PLoS ONE 2020, 15, e0228241. [CrossRef]

61. Shukla, M.R.; Bajwa, V.S.; Freixas-Coutin, J.A.; Saxena, P.K. Salt stress in Arabidopsis thalianaseedlings: Role of indoleamines in stress alleviation. MelatoninRes 2021, 4, 70-83. [CrossRef]

62. Talaat, N.B. Polyamine and nitrogen metabolism regulation by melatonin and salicylic acid combined treatment as a repressor for salt toxicity in wheat (Triticum aestivum L.) plants. Plant. Growth Regul. 2021, 165, 1-15. [CrossRef]

63. Zhao, G.; Zhao, Y.; Yu, X.; Kiprotich, F.; Han, H.; Guan, R.; Wang, R.; Shen, W. Nitric Oxide Is Required for Melatonin-Enhanced Tolerance against Salinity Stress in Rapeseed (Brassica napus L.) Seedlings. Int. J. Mol. Sci. 2018, 19, 1912. [CrossRef]

64. Iqbal, N.; Fatma, M.; Gautam, H.; Umar, S.; Sofo, A.; D'Ippolito, I.; Khan, N.A. The Crosstalk of Melatonin and Hydrogen Sulfide Determines Photosynthetic Performance by Regulation of Carbohydrate Metabolism in Wheat under Heat Stress. Plants 2021, 10, 1778. [CrossRef] 
65. Zhang, J.; Shi, Y.; Zhang, X.; Du, H.; Xu, B.; Huang, B. Melatonin suppression of heat-induced leaf senescence involves changes in abscisic acid and cytokinin biosynthesis and signaling pathways in perennial ryegrass (Lolium perenne L.). Environ. Exp. Bot. 2017, 138, 36-45. [CrossRef]

66. Jahan, M.S.; Shu, S.; Wang, Y.; Chen, Z.; He, M.; Tao, M.; Sun, J.; Guo, S. Melatonin alleviates heat-induced damage of tomato seedlings by balancing redox homeostasis and modulating polyamine and nitric oxide biosynthesis. BMC Plant. Biol. 2019, 19, 1-16. [CrossRef]

67. Gong, X.; Shi, S.; Dou, F.; Song, Y.; Ma, F.; Fangfang, D.; Fengwang, M.; Yi, S.; Xiaoqing, G.; Shuting, S. Exogenous melatonin alleviates alkaline stress in Malus hupehens is Rehd. By regulating the biosynthesis of polyamines. Molecules 2017, $22,1542$. [CrossRef] [PubMed]

68. Ma, X.; Zhang, J.; Burgess, P.; Rossi, S.; Huang, B. Interactive effects of melatonin and cytokinin on alleviating drought-induced leaf senescence in creeping bentgrass (Agrostis stolonifera). Environ. Exp. Bot. 2018, 145, 1-11. [CrossRef]

69. Li, X.; Tan, D.-X.; Jiang, D.; Liu, F. Melatonin enhances cold tolerance in drought-primed wild-type and abscisic acid-deficient mutant barley. J. Pineal Res. 2016, 61, 328-339. [CrossRef]

70. Okant, M.; Kaya, C. The role of endogenous nitric oxide in melatonin-improved tolerance to lead toxicity in maize plants. Environ. Sci. Pollut. Res. 2019, 26, 11864-11874. [CrossRef] [PubMed]

71. Kaya, C.; Okant, M.; Ugurlar, F.; Alyemeni, M.N.; Ashraf, M.; Ahmad, P. Melatonin-mediated nitric oxide improves tolerance to cadmium toxicity by reducing oxidative stress in wheat plants. Chemosphere 2019, 225, 627-638. [CrossRef] [PubMed]

72. Banerjee, A.; Roychoudhary, A. Melatonin application reduces fluoride uptake and toxicity in rice seedlings by altering abscisic acid, gibberellin, auxin and antioxidant homeostasis. Plant. Physiol. Biochem. 2019, 145, 164-173. [CrossRef] [PubMed]

73. Arnao, M.B.; Hernández-Ruiz, J. Melatonin: Plant growth regulator and/or biostimulator during stress? Trends Plant. Sci. 2014, 19, 789-797. [CrossRef] [PubMed]

74. Arnao, M.B.; Hernández-Ruiz, J. Inhibition of ACC oxidase activity by melatonin and indole-3-acetic acid in etiolated lupin hypocotyls. In Advances in Plant Ethylene Research; Springer: Berlin/Heidelberg, Germany, 2007; pp. 101-103.

75. Koyama, F.C.; Carvalho, T.L.G.; Alves, E.; Da Silva, H.B.; Azevedo, M.; Hemerly, A.S.; Garcia, C.R.S. The Structurally Related Auxin and Melatonin Tryptophan-Derivatives and their Roles in Arabidopsis thaliana and in the Human Malaria Parasite Plasmodium falciparum. J. Eukaryot. Microbiol. 2013, 60, 646-651. [CrossRef] [PubMed]

76. Abd El-Naby, S.K.M.; Abdelkhalek, A.; El-Naggar, Y.I.M. Effect of melatonin, GA3 and NAA on vegetative growth, yield and quality of 'Canino'apricot fruits. Acta Sci. Pol. Hortorum. Cultus 2019, 18, 167-174.

77. Li, C.; Tan, D. -X.; Liang, D.; Chang, C.; Jia, D.; Ma, F. Melatonin mediates the regulation of ABA metabolism, free-radical scavenging, and stomatal behaviour in two Malus species under drought stress. J. Exp. Bot. 2015, 66, 669-680. [CrossRef] [PubMed]

78. Dubbels, R.; Reiter, R.; Klenke, E.; Goebel, A.; Schnakenberg, E.; Ehlers, C.; Schiwara, H.; Schloot, W. Melatonin in edible plants identified by radioimmunoassay and by high performance liquid chromatography-mass spectrometry. J. Pineal Res. 1995, 18, 28-31. [CrossRef] [PubMed]

79. Tan, D.-X.; Manchester, L.C.; Esteban-Zubero, E.; Zhou, Z.; Reiter, R.J. Melatonin as a Potent and Inducible Endogenous Antioxidant: Synthesis and Metabolism. Molecules 2015, 20, 18886-18906. [CrossRef]

80. Galano, A.; Reiter, R.J. Melatonin and its metabolites vs oxidative stress: From individual actions to collective protection. J. Pineal Res. 2018, 65, e12514. [CrossRef]

81. Afreen, F.; Zobayed, S.M.A.; Kozai, T. Melatonin in Glycyrrhiza uralensis: Response of plant roots to spectral quality of light and UV-B radiation. J. Pineal Res. 2006, 41, 108-115. [CrossRef] [PubMed]

82. Tan, D.X.; Manchester, L.C.; Hardeland, R.; Lopez-Burillo, S.; Mayo, J.C.; Sainz, R.M.; Reiter, R.J. Melatonin: A hormone, a tissue factor, an autocoid, a paracoid, and an antioxidant vitamin. J. Pineal Res. 2003, 34, 75-78. [CrossRef]

83. Zhang, H.-J.; Zhang, N.; Yang, R.-C.; Wang, L.; Sun, Q.-Q.; Li, D.-B.; Cao, Y.-Y.; Weeda, S.; Zhao, B.; Ren, S.; et al. Melatonin promotes seed germination under high salinity by regulating antioxidant systems, ABA and GA4 interaction in cucumber (Cucumis sativus L.). J. Pineal Res. 2014, 57, 269-279. [CrossRef]

84. Reiter, R.J.; Tan, D.-x.; Manchester, L.C.; Simopoulos, A.P.; Maldonado, M.D.; Flores, L.J.; Terron, M.P. Melatonin in edible plants (phytomelatonin): Identification, concentrations, bioavailability and proposed functions. World Rev. Nutr. Diet. 2007, 97, 211-230.

85. Zhao, D.; Yu, Y.; Shen, Y.; Liu, Q.; Zhao, Z.; Sharma, R.; Reiter, R.J. Melatonin Synthesis and Function: Evolutionary History in Animals and Plants. Front. Endocrinol. 2019, 10, 249. [CrossRef]

86. Tan, D.-X.; Manchester, L.C.; Mascio, P.D.; Martinez, G.R.; Prado, F.M.; Reiter, R.J. Novel rhythms of N1 -acetyl-N2 -formyl5-methoxykynuramine and its precursor melatonin in water hyacinth: Importance for phytoremediation. FASEB J. 2007, 21, 1724-1729. [CrossRef]

87. Arnao, M.B.; Hernández-Ruiz, J. Growth conditions determine different melatonin levels in Lupinus albus L. J. Pineal Res. 2013, 55, 149-155. [CrossRef]

88. Shi, H.; Chen, Y.; Tan, D.-X.; Reiter, R.J.; Chan, Z.; He, C. Melatonin induces nitric oxide and the potential mechanisms relate to innate immunity against bacterial pathogen infection in Arabidopsis. J. Pineal Res. 2015, 59, 102-108. [CrossRef]

89. Shi, H.; Jiang, C.; Ye, T.; Tan, D.-X.; Reiter, R.J.; Zhang, H.; Liu, R.; Chan, Z. Comparative physiological, metabolomic, and transcriptomic analyses reveal mechanisms of improved abiotic stress resistance in bermudagrass [Cynodon dactylon (L). Pers.] by exogenous melatonin. J. Exp. Bot. 2014, 66, 681-694. [CrossRef] 
90. Shi, H.; Reiter, R.J.; Tan, D.-X.; Chan, Z. INDOLE-3-ACETIC ACID INDUCIBLE 17 positively modulates natural leaf senescence through melatonin-mediated pathway in Arabidopsis. J. Pineal Res. 2014, 58, 26-33. [CrossRef]

91. Ye, J.; Wang, S.; Deng, X.; Yin, L.; Xiong, B.; Wang, X. Melatonin increased maize (Zea mays L.) seedling drought tolerance by alleviating drought-induced photosynthetic inhibition and oxidative damage. Acta Physiol. Plant. 2016, 38, 1-13. [CrossRef]

92. Kaya, A.; Doganlar, Z.B. Melatonin improves the multiple stress tolerance in pepper (Capsicum annuum). Sci. Hortic. 2019, 256, 108509. [CrossRef]

93. Szafrańska, K.; Reiter, R.J.; Posmyk, M.M. Melatonin Improves the Photosynthetic Apparatus in Pea Leaves Stressed by Paraquat via Chlorophyll Breakdown Regulation and Its Accelerated de novo Synthesis. Front. Plant Sci. 2017, 8, 878. [CrossRef] [PubMed]

94. Xie, Z.; Wang, J.; Wang, W.; Wang, Y.; Xu, J.; Li, Z.; Zhao, X.; Fu, B. Integrated Analysis of the Transcriptome and Metabolome Revealed the Molecular Mechanisms Underlying the Enhanced Salt Tolerance of Rice Due to the Application of Exogenous Melatonin. Front. Plant Sci. 2021, 11, 618680. [CrossRef]

95. Ding, F.; Wang, M.; Liu, B.; Zhang, S. Exogenous Melatonin Mitigates Photoinhibition by Accelerating Non-photochemical Quenching in Tomato Seedlings Exposed to Moderate Light during Chilling. Front. Plant Sci. 2017, 8, 244. [CrossRef] [PubMed]

96. Fan, J.; Hu, Z.; Xie, Y.; Chan, Z.; Chen, K.; Amombo, E.; Chen, L.; Fu, J. Alleviation of cold damage to photosystem II and metabolisms by melatonin in Bermudagrass. Front. Plant Sci. 2015, 6, 925. [CrossRef] [PubMed]

97. Kobylińska, A.; Reiter, R.J.; Posmyk, M.M. Melatonin Protects Cultured Tobacco Cells against Lead-Induced Cell Death via Inhibition of Cytochrome c Translocation. Front. Plant Sci. 2017, 8, 1560. [CrossRef]

98. Gupta, N.; Thind, S.K.; Bains, N.S. Glycine betaine application modifies biochemical attributes of osmotic adjustment in drought stressed wheat. Plant. Growth Regul. 2013, 72, 221-228. [CrossRef]

99. Sehar, Z.; Jahan, B.; Masood, A.; Anjum, N.A.; Khan, N.A. Hydrogen peroxide potentiates defense system in presence of sulfur to protect chloroplast damage and photosynthesis of wheat under drought stress. Physiol. Plant. 2020, 172, 922-934. [CrossRef] [PubMed]

100. Shao, H.-B.; Chu, L.-Y.; Jaleel, C.A.; Zhao, C.-X. Water-deficit stress-induced anatomical changes in higher plants. Comptes Rendus Biol. 2008, 331, 215-225. [CrossRef]

101. Chaves, M.M.; Maroco, J.P.; Pereira, J.S. Understanding plant responses to drought—from genes to the whole plant. Funct. Plant. Biol. 2003, 30, 239-264. [CrossRef] [PubMed]

102. Wang, P.; Sun, X.; Li, C.; Wei, Z.; Liang, D.; Ma, F. Long-term exogenous application of melatonin delays drought-induced leaf senescence in apple. J. Pineal Res. 2012, 54, 292-302. [CrossRef]

103. Wang, Y.; Wang, Q.; Liu, M.; Bo, C.; Wang, X.; Ma, Q.; Cheng, B.; Cai, R. Overexpression of a maize MYB48 gene confers drought tolerance in transgenic arabidopsis plants. J. Plant. Biol. 2017, 60, 612-621. [CrossRef]

104. Wang, P.; Yin, L.; Liang, D.; Li, C.; Ma, F.; Yue, Z. Delayed senescence of apple leaves by exogenous melatonin treatment: Toward regulating the ascorbate-glutathione cycle. J. Pineal Res. 2011, 53, 11-20. [CrossRef]

105. Liu, L.; Li, D.; Ma, Y.; Shen, H.; Zhao, S.; Wang, Y. Combined Application of Arbuscular Mycorrhizal Fungi and Exogenous Melatonin Alleviates Drought Stress and Improves Plant Growth in Tobacco Seedlings. J. Plant. Growth Regul. 2020, 40, 1074-1087. [CrossRef]

106. Heshmati, S.; Dehaghi, M.A.; Farooq, M.; Wojtyla, L.; Maleki, K.; Heshmati, S. Role of melatonin seed priming on antioxidant enzymes and biochemical responses of Carthamus tinctorius L. under drought stress conditions. Plant Stress 2021, 2, 100023. [CrossRef]

107. Jafari, M.; Shahsavar, A. The Effect of Foliar Application of Melatonin on Changes in Secondary Metabolite Contents in Two Citrus Species under Drought Stress Conditions. Front. Plant Sci. 2021, 12, 1509. [CrossRef] [PubMed]

108. Ren, J.; Yang, X.; Ma, C.; Wang, Y.; Zhao, J. Melatonin enhances drought stress tolerance in maize through coordinated regulation of carbon and nitrogen assimilation. Plant. Physiol. Biochem. 2021, 167, 958-969. [CrossRef] [PubMed]

109. Sarropoulou, V.N.; Therios, I.N.; Dimassi-Theriou, K.N. Melatonin promotes adventitious root regeneration in in vitro shoot tip explants of the commercial sweet cherry rootstocks CAB-6P (Prunus cerasus L.), Gisela 6 (P. cerasus $\times$ P. canescens), and MxM 60 (P. avium $\times$ P. mahaleb). J. Pineal Res. 2011, 52, 38-46. [CrossRef]

110. Liang, D.; Ni, Z.; Xia, H.; Xie, Y.; Lv, X.; Wang, J.; Luo, X. Exogenous melatonin promotes biomass accumulation and photosynthesis of kiwifruit seedlings under drought stress. Sci. Hortic. 2019, 246, 34-43. [CrossRef]

111. Cui, G.; Zhao, X.; Liu, S.; Sun, F.; Zhang, C.; Xi, Y. Beneficial effects of melatonin in overcoming drought stress in wheat seedlings. Plant. Physiol. Biochem. 2017, 118, 138-149. [CrossRef] [PubMed]

112. Rahmati, M.; Mirás-Avalos, J.M.; Valsesia, P.; Lescourret, F.; Génard, M.; Davarynejad, G.H.; Vercambre, G. Disentangling the effects of water stress on carbon acquisition, vegetative growth, and fruit quality of peach trees by means of the QualiTree mod-el. Front. Plant Sci. 2018, 9, 3. [CrossRef]

113. Gao, W.; Zhang, Y.; Feng, Z.; Bai, Q.; He, J.; Wang, Y. Effects of Melatonin on Antioxidant Capacity in Naked Oat Seedlings under Drought Stress. Molecules 2018, 23, 1580. [CrossRef]

114. Tiwari, R.K.; Lal, M.K.; Kumar, R.; Chourasia, K.N.; Naga, K.C.; Kumar, D.; Das, S.K.; Zinta, G. Mechanistic insights on melatonin-mediated drought stress mitigation in plants. Physiol. Plant. 2020, 172, 1212-1226. [CrossRef]

115. Sadak, M.S.; Ramadan, A.A.E.-M. Impact of melatonin and tryptophan on water stress tolerance in white lupine (Lupinus termis L.). Physiol. Mol. Biol. Plants 2021, 27, 469-481. [CrossRef] 
116. Hussain, K.A.; Majeed, A.; Nawaz, K.; Nisar, M.F. Changes in morphological attributes of maize (Zea mays L.) under NaCl salinity. Am.-Eurasian J. Agric. Environ. Sci. 2011, 8, 230-232.

117. Khan, N.A.; Khan, M.I.R.; Asgher, M.; Fatma, M.; Masood, A.; Syeed, S. Salinity Tolerance in Plants: Revisiting the Role of Sulfur Metabolites. J. Plant. Biochem. Physiol. 2014, 2, 120.

118. Fatma, M.; Asgher, M.; Masood, A.; Khan, N.A. Excess sulfur supplementation improves photosynthesis and growth in mustard under salt stress through increased production of glutathione. Environ. Exp. Bot. 2014, 107, 55-63. [CrossRef]

119. Calone, R.; Bregaglio, S.; Sanoubar, R.; Noli, E.; Lambertini, C.; Barbanti, L. Physiological Adaptation to Water Salinity in Six Wild Halophytes Suitable for Mediterranean Agriculture. Plants 2021, 10, 309. [CrossRef] [PubMed]

120. Yan, F.; Wei, H.; Li, W.; Liu, Z.; Tang, S.; Chen, L.; Ding, C.; Jiang, Y.; Ding, Y.; Li, G. Melatonin improves K+ and Na+ homeostasis in rice under salt stress by mediated nitric oxide. Ecotoxicol. Environ. Saf. 2020, 206, 111358. [CrossRef]

121. Yan, F.; Wei, H.; Li, W.; Liu, Z.; Tang, S.; Chen, L.; Li, G. Melatonin enhances Na+/K+ homeostasis in rice seedlings under salt stress through increasing the root $\mathrm{H}+-$ pump activity and $\mathrm{Na}+/ \mathrm{K}+$ transporters sensitivity to ROS/RNS. Environ. Exp. Bot. 2021, 182, 104328. [CrossRef]

122. Ke, Q.; Ye, J.; Wang, B.; Ren, J.; Yin, L.; Deng, X.; Wang, S. Melatonin Mitigates Salt Stress in Wheat Seedlings by Modulating Polyamine Metabolism. Front. Plant Sci. 2018, 9, 914. [CrossRef]

123. Zhou, X.; Zhao, H.; Cao, K.; Hu, L.; Du, T.; Baluška, F.; Zou, Z. Beneficial Roles of Melatonin on Redox Regulation of Photosynthetic Electron Transport and Synthesis of D1 Protein in Tomato Seedlings under Salt Stress. Front. Plant Sci. 2016, 7, 1823. [CrossRef]

124. El-Sayed, A.I.; Rafudeen, M.S.; Gomaa, A.M.; Hasanuzzaman, M. Exogenous melatonin enhances the reactive oxygen species metabolism, antioxidant defense-related gene expression, and photosynthetic capacity of Phaseolus vulgaris L. to confer salt stress tolerance. Physiol. Plantarum 2021. [CrossRef] [PubMed]

125. Cen, H.; Wang, T.; Liu, H.; Tian, D.; Zhang, Y. Melatonin application improves salt tolerance of alfalfa (Medicago sativa L.) by enhancing antioxidant capacity. Plants 2020, 9, 220. [CrossRef]

126. Goh, C.-H.; Ko, S.-M.; Koh, S.; Kim, Y.-J.; Bae, H.-J. Photosynthesis and Environments: Photoinhibition and Repair Mechanisms in Plants. J. Plant. Biol. 2011, 55, 93-101. [CrossRef]

127. Farooq, M.; Wahid, A.; Kobayashi, N.; Fujita, D.; Basra, S.M.A. Plant drought stress: Effects, mechanisms and management. In Sustainable Agriculture; Springer: Berlin/Heidelberg, Germany, 2009; pp. 153-188.

128. Turk, H.; Erdal, S.; Genisel, M.; Atici, O.; Demir, Y.; Yanmis, D. The regulatory effect of melatonin on physiological, biochemical and molecular parameters in cold-stressed wheat seedlings. Plant. Growth Regul. 2014, 74, 139-152. [CrossRef]

129. Adam, A.M.A.; Altalhi, T.A.; El-Megharbel, S.M.; Saad, H.A.; Refat, M.S. Using a Modified Polyamidoamine Fluorescent Dendrimer for Capturing Environment Polluting Metal Ions $\mathrm{Zn}^{2+}, \mathrm{Cd}^{2+}$, and $\mathrm{Hg}^{2+}$ : Synthesis and Characterizations. Crystals 2021, 11, 92. [CrossRef]

130. Wang, M.; Zhang, S.; Ding, F. Melatonin Mitigates Chilling-Induced Oxidative Stress and Photosynthesis Inhibition in Tomato Plants. Antioxidants 2020, 9, 218. [CrossRef]

131. Kang, K.; Lee, K.; Park, S.; Kim, Y.S.; Back, K. Enhanced production of melatonin by ectopic overexpression of human serotonin $\mathrm{N}$-acetyltransferase plays a role in cold resistance in transgenic rice seedlings. J. Pineal Res. 2010, 49, 176-182. [CrossRef]

132. Zhao, Y.; Qi, L.-W.; Wang, W.-M.; Saxena, P.K.; Liu, C.-Z. Melatonin improves the survival of cryopreserved callus of Rhodiola crenulata. J. Pineal Res. 2010, 50, 83-88. [CrossRef]

133. Szafrańska, K.; Glińska, S.; Janas, K.M. Ameliorative effect of melatonin on meristematic cells of chilled and re-warmed Vigna radiata roots. Biol. Plant. 2013, 57, 91-96. [CrossRef]

134. Bajwa, V.S.; Shukla, M.R.; Sherif, S.; Murch, S.J.; Saxena, P.K. Role of melatonin in alleviating cold stress in Arabidopsis thaliana. J. Pineal Res. 2014, 56, 238-245. [CrossRef]

135. Shi, H.; Chan, Z. The cysteine2/histidine2-type transcription factor ZINC FINGER OF ARABIDOPSIS THALIANA 6 -activated C-REPEAT-BINDING FACTOR pathway is essential for melatonin-mediated freezing stress resistance in Arabidopsis. J. Pineal Res. 2014, 57, 185-191. [CrossRef] [PubMed]

136. Skinner, J.S.; Von Zitzewitz, J.; Szúcs, P.; Marquez-Cedillo, L.; Filichkin, T.; Amundsen, K.; Stockinger, E.J.; Thomashow, M.F.; Chen, T.H.; Hayes, P.M. Structural, Functional, and Phylogenetic Characterization of a Large CBF Gene Family in Barley. Plant. Mol. Biol. 2005, 59, 533-551. [CrossRef] [PubMed]

137. Bawa, G.; Feng, L.; Shi, J.; Chen, G.; Cheng, Y.; Luo, J.; Wu, W.; Ngoke, B.; Cheng, P.; Tang, Z.; et al. Evidence that melatonin promotes soybean seedlings growth from low-temperature stress by mediating plant mineral elements and genes involved in the antioxidant pathway. Funct. Plant. Biol. 2020, 47, 815. [CrossRef] [PubMed]

138. Zhang, H.; Liu, L.; Wang, Z.; Feng, G.; Gao, Q.; Li, X. Induction of Low Temperature Tolerance in Wheat by Pre-Soaking and Parental Treatment with Melatonin. Molecules 2021, 26, 1192. [CrossRef] [PubMed]

139. Chang, T.; Zhao, Y.; He, H.; Xi, Q.; Fu, J.; Zhao, Y. Exogenous melatonin improves growth in hulless barley seedlings under cold stress by influencing the expression rhythms of circadian clock genes. PeerJ 2021, 9, e10740. [CrossRef] [PubMed]

140. Barand, A.; Nasibi, F.; Kalantari, K.M.; Moradi, M. The effects of foliar application of melatonin on some physiological and biochemical characteristics and expression of fatty acid desaturase gene in pistachio seedlings (Pistacia vera L.) under freezing stress. J. Plant. Interact. 2020, 15, 257-265. [CrossRef] 
141. Kong, X.-M.; Ge, W.-Y.; Wei, B.-D.; Zhou, Q.; Zhou, X.; Zhao, Y.-B.; Ji, S.-J. Melatonin ameliorates chilling injury in green bell peppers during storage by regulating membrane lipid metabolism and antioxidant capacity. Postharvest Biol. Technol. 2020, 170, 111315. [CrossRef]

142. Kołodziejczyk, I.; Kaźmierczak, A.; Posmyk, M.M. Melatonin Application Modifies Antioxidant Defense and Induces Endoreplication in Maize Seeds Exposed to Chilling Stress. Int. J. Mol. Sci. 2021, 22, 8628. [CrossRef]

143. Turk, H.; Genisel, M. Melatonin-related mitochondrial respiration responses are associated with growth promotion and cold tolerance in plants. Cryobiology 2019, 92, 76-85. [CrossRef]

144. Liu, G.; Zhang, Y.; Yun, Z.; Hu, M.; Liu, J.; Jiang, Y.; Zhang, Z. Melatonin Enhances Cold Tolerance by Regulating Energy and Proline Metabolism in Litchi Fruit. Foods 2020, 9, 454. [CrossRef]

145. Du, H.; Liu, G.; Hua, C.; Liu, D.; He, Y.; Liu, H.; Kurtenbach, R.; Ren, D. Exogenous melatonin alleviated chilling injury in harvested plum fruit via affecting the levels of polyamines conjugated to plasma membrane. Postharvest Biol. Technol. 2021, 179, 111585. [CrossRef]

146. Miranda, S.; Vilches, P.; Suazo, M.; Pavez, L.; García, K.; Méndez, M.A.; González, M.; Meisel, L.A.; Defilippi, B.G.; del Pozo, T. Melatonin triggers metabolic and gene expression changes leading to improved quality traits of two sweet cherry cultivars during cold storage. Food Chem. 2020, 319, 126360. [CrossRef]

147. Asgher, M.; Ahmed, S.; Sehar, Z.; Gautam, H.; Gandhi, S.G.; Khan, N.A. Hydrogen peroxide modulates activity and expression of antioxidant enzymes and protects photosynthetic activity from arsenic damage in rice (Oryza sativa L.). J. Hazard. Mater. 2020, 401, 123365. [CrossRef] [PubMed]

148. Asgher, M.; Per, T.S.; Verma, S.; Pandith, S.; Masood, A.; Khan, N.A. Ethylene Supplementation Increases PSII Efficiency and Alleviates Chromium-Inhibited Photosynthesis through Increased Nitrogen and Sulfur Assimilation in Mustard. J. Plant. Growth Regul. 2018, 37, 1300-1317. [CrossRef]

149. Moustafa-Farag, M.; Elkelish, A.; Dafea, M.; Khan, M.; Arnao, M.B.; Abdelhamid, M.T.; Abu El-Ezz, A.; Almoneafy, A.; Mahmoud, A.; Awad, M.; et al. Role of Melatonin in Plant Tolerance to Soil Stressors: Salinity, pH and Heavy Metals. Molecules 2020, $25,5359$. [CrossRef] [PubMed]

150. Reeves, R.D.; Baker, A.J.M. Metal-accumulating plants. In Phytoremediation of Toxic Metals; Raskin, I., Ensley, B.D., Eds.; Wiley: New York, NY, USA, 2000; pp. 193-221.

151. Yu, Y.; Teng, Z.; Mou, Z.; Lv, Y.; Li, T.; Chen, S.; Zhao, D.; Zhao, Z. Melatonin confers heavy metal-induced tolerance by alleviating oxidative stress and reducing the heavy metal accumulation in Exophiala pisciphila, a dark septate endophyte (DSE). BMC Microbiol. 2021, 21, 40. [CrossRef] [PubMed]

152. Hasan, K.; Ahammed, G.J.; Yin, L.; Shi, K.; Xia, X.; Zhou, Y.; Yu, J.; Zhou, J. Melatonin mitigates cadmium phytotoxicity through modulation of phytochelatins biosynthesis, vacuolar sequestration, and antioxidant potential in Solanum lycopersicum L. Front. Plant Sci. 2015, 6, 601. [CrossRef] [PubMed]

153. Xu, L.; Zhang, F.; Tang, M.; Wang, Y.; Dong, J.; Ying, J.; Chen, Y.; Hu, B.; Li, C.; Liu, L. Melatonin confers cadmium tolerance by modulating critical heavy metal chelators and transporters in radish plants. J. Pineal Res. 2020, 69, e12659. [CrossRef] [PubMed]

154. Wu, S.; Wang, Y.; Zhang, J.; Gong, X.; Zhang, Z.; Sun, J.; Chen, X.; Wang, Y. Exogenous Melatonin Improves Physiological Characteristics and Promotes Growth of Strawberry Seedlings Under Cadmium Stress. Hortic. Plant. J. 2020, 7, 13-22. [CrossRef]

155. Li, L.; Yan, X. Insights into the Roles of Melatonin in Alleviating Heavy Metal Toxicity in Crop Plants. Phyton 2021, 90, 1559-1572. [CrossRef]

156. Tousi, S.; Zoufan, P.; Ghahfarrokhie, A.R. Alleviation of cadmium-induced phytotoxicity and growth improvement by exogenous melatonin pretreatment in mallow (Malva parviflora) plants. Ecotoxicol. Environ. Saf. 2020, 206, 111403. [CrossRef] [PubMed]

157. Pardo-Hernández, M.; López-Delacalle, M.; Martí-Guillen, J.M.; Martínez-Lorente, S.E.; Rivero, R.M. ROS and NO Phytomelatonin-Induced Signaling Mechanisms under Metal Toxicity in Plants. Antioxidants 2021, 10, 775. [CrossRef] [PubMed]

158. Tang, M.; Xu, L.; Wang, Y.; Dong, J.; Zhang, X.; Wang, K.; Ying, J.; Li, C.; Liu, L. Melatonin-induced DNA demethylation of metal transporters and antioxidant genes alleviates lead stress in radish plants. Hortic. Res. 2021, 8, 124. [CrossRef] [PubMed]

159. Samanta, S.; Singh, A.; Banerjee, A.; Roychoudhury, A. Exogenous supplementation of melatonin alters representative organic acids and enzymes of respiratory cycle as well as sugar metabolism during arsenic stress in two contrasting indica rice cultivars. J. Biotechnol. 2020, 324, 220-232. [CrossRef] [PubMed]

160. Hodžić, E.; Galijašević, S.; Balaban, M.; Rekanović, S.; Makić, H.; Kukavica, B.; Mihajlović, D. The protective role of melatonin under heavy metal-induced stress in Melissa Officinalis L. Turk. J. Chem. 2021, 45, 737-748. [CrossRef]

161. Seleiman, M.F.; Ali, S.; Refay, Y.; Rizwan, M.; Alhammad, B.A.; El-Hendawy, S.E. Chromium resistant microbes and melatonin reduced $\mathrm{Cr}$ uptake and toxicity, improved physio-biochemical traits and yield of wheat in contaminated soil. Chemosphere 2020, 250, 126239. [CrossRef]

162. Sami, A.; Shah, F.A.; Abdullah, M.; Yu, Z.X.; Yan, Y.; He, Z.Z.; Jin, Z.K. Melatonin mitigates Cadmium and Aluminum toxicity through modulation of antioxidant potential in Brassica napus L. Plant. Biol. 2020, 22, 679-690. [CrossRef]

163. Namdjoyan, S.; Soorki, A.A.; Elyasi, N.; Kazemi, N.; Simaei, M. Melatonin alleviates lead-induced oxidative damage in safflower (Carthamus tinctorius L.) seedlings. Ecotoxicology 2019, 29, 108-118. [CrossRef]

164. Mohamed, H.A.; Moussa, H.R.; Selem, E.; El-Deen Sayed Ragab, M.H. Does Exogenous Application of Melatonin Ameliorate Lead Toxicity in Eruca vesicaria Plants? Egypt. J. Bot. 2021, 61, 33-40. 
165. Lukatkin, A.S.; Gar'Kova, A.N.; Bochkarjova, A.S.; Nushtaeva, O.V.; da Silva, J.A.T. Treatment with the herbicide TOPIK induces oxidative stress in cereal leaves. Pestic. Biochem. Physiol. 2013, 105, 44-49. [CrossRef]

166. Fayez, K.A.; Radwan, D.E.M.; Mohamed, A.K.; Abdelrahman, A.M. Fusilade herbicide causes alterations in chloroplast ultrastructure, pigment content and physiological activities of peanut leaves. Photosynthetica 2014, 52, 548-554. [CrossRef]

167. Kaya, A.; Doganlar, Z.B. Exogenous jasmonic acid induces stress tolerance in tobacco (Nicotiana tabacum) exposed to imazapic. Ecotoxicol. Environ. Saf. 2016, 124, 470-479. [CrossRef] [PubMed]

168. El-Awadi, M.E.; Hassan, E.A. Improving growth and productivity of fennel plant exposed to pendimethalin herbicide: Stressrecovery treatments. Nat. Sci. 2011, 9, 97-108.

169. Nabiha, B.; Reda, D.M.; Noureddine, Z.; Houria, B. Differential response to treatment with herbicide chevalier induced oxidative stress in leaves of wheat. Ann. Biol. Res. 2014, 5, 1-7.

170. Badr, A.; Zaki, H.; Germoush, M.O.; Tawfeek, A.Q.; El-Tayeb, M.A. Cytophysiological impacts of Metosulam herbicide on Vicia faba plants. Acta Physiol. Plant. 2013, 35, 1933-1941. [CrossRef]

171. Sergiev, I.G.; Alexieva, V.S.; Ivanov, S.V.; Moskova, I.I.; Karanov, E.N. The phenyl urea cytokinin 4 PU-30 protects maize plants against glyphosate action. Pestic. Biochem. Physiol. 2006, 85, 139-146. [CrossRef]

172. Wang, M.; Zhou, Q. Effects of herbicide chlorimuron-ethyl on physiological mechanisms in wheat (Triticum aestivum). Ecotoxicol. Environ. Saf. 2006, 64, 190-197. [CrossRef] [PubMed]

173. Ding, F.; Wang, G.; Zhang, S. Exogenous Melatonin Mitigates Methyl Viologen-Triggered Oxidative Stress in Poplar Leaf. Molecules 2018, 23, 2852. [CrossRef]

174. Liu, N.; Li, J.; Lv, J.; Yu, J.; Xie, J.; Wu, Y.; Tang, Z. Melatonin alleviates imidacloprid phytotoxicity to cucumber (Cucumis sativus L.) through modulating redox homeostasis in plants and promoting its metabolism by enhancing glutathione dependent detoxification, Ecotoxicol. Environ. Saf. 2021, 217, 112248.

175. Caputo, G.A.; Wadl, P.A.; Mccarty, L.; Adelberg, J.; Jennings, K.M.; Cutulle, M. In Vitro Safening of Bentazon by Melatonin in Sweetpotato (Ipomoea batatas). HortScience 2020, 55, 1406-1410. [CrossRef]

176. Ahammed, G.J.; Li, X.; Zhou, J.; Zhou, Y.H.; Yu, J.Q. Role of hormones in plant adaptation to heat stress. In Plant Hormones under Challenging Environmental Factors; Ahammed, G.J., Yu, J.Q., Eds.; Springer: Berlin/Heidelberg, Germany, 2016 ; pp. 1-21.

177. Lesk, C.; Rowhani, P.; Ramankutty, N. Influence of extreme weather disasters on global crop production. Nature 2016, 529, 84-87. [CrossRef]

178. Tal, O.; Haim, A.; Harel, O.; Gerchman, Y. Melatonin as an antioxidant and its semi-lunar rhythm in green macroalga Ulva sp. J. Exp. Botany 2011, 62, 1903-1910. [CrossRef]

179. Tiryaki, I.; Keles, H. Reversal of the inhibitory effect of light and high temperature on germination of Phaceliatan acetifolia seeds by melatonin. J. Pineal Res. 2012, 52, 332-339. [CrossRef]

180. Hernández, I.G.; Gomez, F.J.V.; Cerutti, S.; Arana, M.V.; Silva, M.F. Melatonin in Arabidopsis thaliana acts as plant growth regulator at low concentrations and preserves seed viability at high concentrations. Plant. Physiol. Biochem. 2015, 94, 191-196. [CrossRef]

181. Ahammed, G.J.; Xu, W.; Liu, A.; Chen, S. Endogenous melatonin deficiency aggravates high temperature-induced oxidative stress in Solanum lycopersicum L. Environ. Exp. Bot. 2019, 161, 303-311. [CrossRef]

182. Xu, W.; Cai, S.-Y.; Zhang, Y.; Wang, Y.; Ahammed, G.J.; Xia, X.-J.; Shi, K.; Zhou, Y.-H.; Yu, J.-Q.; Reiter, R.J.; et al. Melatonin enhances thermotolerance by promoting cellular protein protection in tomato plants. J. Pineal Res. 2016, 61, 457-469. [CrossRef] [PubMed]

183. Li, H.; He, J.; Yang, X.; Li, X.; Luo, D.; Wei, C.; Ma, J.; Zhang, Y.; Yang, J.; Zhang, X. Glutathione-dependent induction of local and systemic defense against oxidative stress by exogenous melatonin in cucumber (Cucumis sativus L.). J. Pineal Res. 2016, 60, 206-216. [CrossRef]

184. Qi, Z.-Y.; Wang, K.-X.; Yan, M.-Y.; Kanwar, M.K.; Li, D.-Y.; Wijaya, L.; Alyemeni, M.N.; Ahmad, P.; Zhou, J. Melatonin Alleviates High Temperature-Induced Pollen Abortion in Solanum lycopersicum. Molecules 2018, 23, 386. [CrossRef] [PubMed]

185. Zhao, N.; Sun, Y.; Wang, D.Y.; Zheng, J.X. Effects of exogenous melatonin on nitrogen metabolism in cucumber seedlings under high temperature stress. Plant. Physiol. Commun. 2012, 48, 557-564.

186. Pardo-Hernández, M.; López-Delacalle, M.; Rivero, R. ROS and NO Regulation by Melatonin under Abiotic Stress in Plants. Antioxidants 2020, 9, 1078. [CrossRef] [PubMed]

187. Zhu, Y.; Gao, H.; Lu, M.; Hao, C.; Pu, Z.; Guo, M.; Hou, D.; Chen, L.-Y.; Huang, X. Melatonin-Nitric Oxide Crosstalk and Their Roles in the Redox Network in Plants. Int. J. Mol. Sci. 2019, 20, 6200. [CrossRef]

188. Hu, Z.; Fu, Q.; Zheng, J.; Zhang, A.; Wang, H. Transcriptomic and metabolomic analyses reveal that melatonin promotes melon root development under copper stress by inhibiting jasmonic acid biosynthesis. Hortic. Res. 2020, 7, 1-15. [CrossRef]

189. Huyi, H.; Long-Fei, H. Crosstalk between melatonin and nitric oxide in plant development and stress responses. Physiol. Plantarum. 2020, 170, 218-226.

190. Aghdam, M.S.; Luo, Z.; Jannatizadeh, A.; Sheikh-Assadi, M.; Sharafi, Y.; Farmani, B.; Fard, J.R.; Razavi, F. Employing exogenous melatonin applying confers chilling tolerance in tomato fruits by upregulating ZAT2/6/12 giving rise to promoting endogenous polyamines, proline, and nitric oxide accumulation by triggering arginine pathway activity. Food Chem. 2019, 275, 549-556. [CrossRef] 
191. Liu, J.; Yang, J.; Zhang, H.; Cong, L.; Zhai, R.; Yang, C.; Wang, Z.; Ma, F.; Xu, L. Melatonin Inhibits Ethylene Synthesis via Nitric Oxide Regulation to Delay Postharvest Senescence in Pears. J. Agric. Food Chem. 2019, 67, 2279-2288. [CrossRef]

192. Lv, Y.; Pan, J.; Wang, H.; Reiter, R.J.; Li, X.; Mou, Z.; Zhang, J.; Yao, Z.; Zhao, D.; Yu, D. Melatonin inhibits seed germination by crosstalk with abscisic acid, gibberellin, and auxin in Arabidopsis. J. Pineal Res. 2021, 70, e12736. [CrossRef] [PubMed]

193. Li, H.; Guo, Y.; Lan, Z.; Zhang, Z.; Ahammed, G.J.; Chang, J.; Zhang, Y.; Wei, C.; Zhang, X. Melatonin antagonizes ABA action to promote seed germination by regulating $\mathrm{Ca}^{2+}$ efflux and $\mathrm{H}^{2} \mathrm{O}^{2}$ accumulation. Plant. Sci. 2020, 303, 110761. [CrossRef] [PubMed]

194. Zhang, W.; Cao, J.; Fan, X.; Jiang, W. Applications of nitric oxide and melatonin in improving postharvest fruit quality and the separate and crosstalk biochemical mechanisms. Trends Food Sci. Technol. 2020, 99, 531-541. [CrossRef]

195. Hu, W.; Zhang, J.; Yan, K.; Zhou, Z.; Zhao, W.; Zhang, X.; Pu, Y.; Yu, R. Beneficial effects of abscisic acid and melatonin in overcoming drought stress in cotton (Gossypium hirsutum L.). Physiol. Plant. 2021. [CrossRef] [PubMed]

196. Imran, M.; Khan, A.L.; Shahzad, R.; Khan, M.A.; Bilal, S.; Khan, A.; Kang, S.-M.; Lee, I.-J. Exogenous melatonin induces drought stress tolerance by promoting plant growth and antioxidant defence system of soybean plants. AoB Plants 2021, 13, plab026. [CrossRef]

197. Pan, J.; Lin, S.; Woodbury, N.W. Bacteriochlorophyll Excited-State Quenching Pathways in Bacterial Reaction Centers with the Primary Donor Oxidized. J. Phys. Chem. 2012, 116, 2014-2022. [CrossRef]

198. Chen, Y.-E.; Mao, J.-J.; Sun, L.-Q.; Huang, B.; Ding, C.-B.; Gu, Y.; Liao, J.-Q.; Hu, C.; Zhang, Z.-W.; Yuan, S.; et al. Exogenous melatonin enhances salt stress tolerance in maize seedlings by improving antioxidant and photosynthetic capacity. Physiol. Plant. 2018, 164, 349-363. [CrossRef] [PubMed]

199. Demmig-Adams, B.; Stewart, J.J.; Baker, C.R.; Adams, W.W. Optimization of Photosynthetic Productivity in Contrasting Environments by Regulons Controlling Plant Form and Function. Int. J. Mol. Sci. 2018, 19, 872. [CrossRef] [PubMed]

200. Mir, S.; Alam, H. Melatonin modulates photosynthesis, redox status, and elemental composition to promote growth of Brassica juncea-a dose-dependent effect. Protoplasma 2020, 257, 1685-1700. [CrossRef] [PubMed]

201. Zhan, H.; Nie, X.; Zhang, T.; Li, S.; Wang, X.; Du, X.; Tong, W.; Song, W. Melatonin: A Small Molecule but Important for Salt Stress Tolerance in Plants. Int. J. Mol. Sci. 2019, 20, 709. [CrossRef]

202. Yin, Z.; Lu, J.; Meng, S.; Liu, Y.; Mostafa, I.; Qi, M.; Li, T. Exogenous melatonin improves salt tolerance in tomato by regulating photosynthetic electron flux and the ascorbate-glutathione cycle. J. Plant. Interactions 2019, 14, 453-463. [CrossRef]

203. Lazar, D.; Murch, S.J.; Beilby, M.J.; Al Khazaaly, S. Exogenous melatonin affects photosynthesis in characeae Chara australis. Plant. Signal. Behav. 2013, 8, e23279. [CrossRef]

204. Yang, Y.; Yan, L.; Yana, S.; Tao, L.; Yanchun, C.; Dake Zhao, I.D.; Zhao, Z. The Role of Phyto-Melatonin and Related Metabolites in Response to Stress. Molecules 2018, 23, 1887.

205. Arnao, M.B.; Ruiz, J.H. Chemical stress by different agents affects the melatonin content of barley roots. J. Pineal Res. 2009, 46, 295-299. [CrossRef]

206. Karaca, P.; Cekic, F. Exogenous melatonin-stimulated defense responses in tomato plants treated with polyethylene glycol. Int. J. Veg. Sci. 2019, 25, 601-609. [CrossRef]

207. Liang, B.; Ma, C.; Zhang, Z.; Wei, Z.; Gao, T.; Zhao, Q.; Ma, F.; Li, C. Long-term exogenous application of melatonin improves nutrient uptake fluxes in apple plants under moderate drought stress. Environ. Exp. Bot. 2018, 155, 650-661. [CrossRef]

208. Sharma, A.; Wang, J.; Xu, D.; Tao, S.; Chong, S.; Yan, D.; Li, Z.; Yuan, H.; Zheng, B.; Wang, J.; et al. Melatonin regulates the functional components of photosynthesis, antioxidant system, gene expression, and metabolic pathways to induce drought re-sistance in grafted Carya cathayensis plants Melatonin regulates the functional components. Sci. Total Environ. 2020, 713, 136675. [CrossRef]

209. Campos, C.N.; Ávila, R.G.; de Souza, K.R.D.; Azevedo, L.M.; Alves, J.D. Melatonin reduces oxidative stress and promotes drought tolerance in young Coffea arabica L. plants. Agric. Water Manag. 2018, 211, 37-47. [CrossRef]

210. Antoniou, C.; Chatzimichail, G.; Xenofontos, R.; Pavlou, J.J.; Panagiotou, E.; Christou, A.; Fotopoulos, V. Meatonin systemically ameliorates drought stress-induced damage in Medicago sativa plants by modulating nitro-oxidative homeostasis and proline metabolism. J. Pineal. Res. 2017, 62, e12401. [CrossRef] [PubMed]

211. Choudhary, A.; Kumar, A.; Kaur, N. ROS and oxidative burst: Roots in plant development. Plant. Divers. 2019, 42, 33-43. [CrossRef] [PubMed]

212. Hossain, S.; Li, J.; Sikdar, A.; Hasanuzzaman, M.; Uzizerimana, F.; Muhammad, I.; Yuan, Y.; Zhang, C.; Wang, C.; Feng, B. Exogenous Melatonin Modulates the Physiological and Biochemical Mechanisms of Drought Tolerance in Tartary Buckwheat (Fagopyrum tataricum (L.) Gaertn). Molecules 2020, 25, 2828. [CrossRef]

213. Janas, K.M.; Posmyk, M.M. Melatonin, an underestimated natural substance with great potential for agricultural application. Acta Physiol. Plant. 2013, 35, 3285-3292. [CrossRef]

214. Arnao, M.B.; Hernández-Ruiz, J. Melatonin as a Chemical Substance or as Phytomelatonin Rich-Extracts for Use as Plant Protector and/or Biostimulant in Accordance with EC Legislation. Agronomy 2019, 9, 570. [CrossRef]

215. Pérez-Llamas, F.; Hernández-Ruiz, J.; Cuesta, A.; Zamora, S.; Arnao, M.B. Development of a Phytomelatonin-Rich Extract from Cultured Plants with Excellent Biochemical and Functional Properties as an Alternative to Synthetic Melatonin. Antioxidants 2020, 9, 158. [CrossRef] 